\title{
Increased Seizure Susceptibility in Mice Lacking Metabotropic Glutamate Receptor 7
}

\author{
Gilles Sansig,, ${ }^{1}$ Trevor J. Bushell, ${ }^{2}$ Vernon R. J. Clarke, ${ }^{2}$ Andrei Rozov, ${ }^{3}$ Nail Burnashev, ${ }^{3}$ Chantal Portet, ${ }^{1}$ \\ Fabrizio Gasparini, ${ }^{1}$ Markus Schmutz, ${ }^{1}$ Klaus Klebs, ${ }^{1}$ Ryuichi Shigemoto, ${ }^{4}$ Peter J. Flor, ${ }^{1}$ Rainer Kuhn, ${ }^{1}$ \\ Thomas Knoepfel, ${ }^{1}$ Markus Schroeder, ${ }^{1}$ David R. Hampson, ${ }^{5}$ Valerie J. Collett, ${ }^{2}$ Congxiao Zhang, ${ }^{6}$ \\ Robert M. Duvoisin, ${ }^{6}$ Graham L. Collingridge, ${ }^{2}$ and Herman van der Putten ${ }^{1}$
}

\begin{abstract}
${ }^{1}$ Nervous System Department, Novartis Pharma AG, CH-4002 Basel, Switzerland, ${ }^{2}$ Medical Research Council Center for Synaptic Plasticity, Department of Anatomy, The School of Medical Sciences, University of Bristol, Bristol, BS8 1TD, United Kingdom, ${ }^{3}$ Abteilung Zellphysiologie, Max-Planck-Institut für Medizinische Forschung, D-69120 Heidelberg, Germany, ${ }^{4}$ Division of Cerebral Structure, National Institute for Physiological Sciences, Myodaiji, Okazaki 444-8585, Japan, ${ }^{5}$ Faculty of Pharmacy and Department of Pharmacology, University of Toronto, Ontario, Canada M5S 2S2, and 6Margaret M. Dyson Vision Research Institute, Department of Ophthalmology, Cornell University Medical College, New York, New York 10021
\end{abstract}

To study the role of mGlu7 receptors (mGluR7), we used homologous recombination to generate mice lacking this metabotropic receptor subtype (mGluR7 ${ }^{-\prime-}$ ). After the serendipitous discovery of a sensory stimulus-evoked epileptic phenotype, we tested two convulsant drugs, pentylenetetrazole (PTZ) and bicuculline. In animals aged 12 weeks and older, subthreshold doses of these drugs induced seizures in $\mathrm{mGluR7^{-1- }}{ }^{\text {, but not }}$

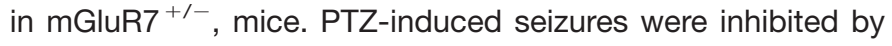
three standard anticonvulsant drugs, but not by the group III selective mGluR agonist (R,S)-4-phosphonophenylglycine (PPG). Consistent with the lack of signs of epileptic activity in the absence of specific stimuli, mGluR7 ${ }^{-1-}$ mice showed no major changes in synaptic properties in two slice preparations. However, slightly increased excitability was evident in hippocampal slices. In addition, there was slower recovery from frequency facilitation in cortical slices, suggesting a role for mGluR7 as a frequency-dependent regulator in presynaptic terminals. Our findings suggest that mGluR7 receptors have a unique role in regulating neuronal excitability and that these receptors may be a novel target for the development of anticonvulsant drugs.

Key words: epilepsy; mGluR7; knock-out; mice; group III mGluR; (R,S)-4-phosphonophenylglycine
An imbalance in glutamatergic excitatory neurotransmission and GABAergic synaptic inhibition in the vertebrate CNS can cause seizures and may be a major cause of epilepsy. There is, therefore, considerable interest in how these neurotransmitter systems are regulated physiologically. Metabotropic glutamate receptors (mGluRs) couple to G-proteins and can modulate L-glutamate release, GABA release, and neuronal excitability (Conn and Pin, 1997). They are subdivided into groups I (mGluR1, mGluR5), II (mGluR2, mGluR3), and III (mGluR4, mGluR6, mGluR7,

\footnotetext{
Received April 9, 2001; revised July 30, 2001; accepted Sept. 5, 2001.

This work was supported in part by the Biotechnology and Biological Sciences Research Council and Medical Research Council (UK). We thank Doris Ruegg for sequencing, Gemma Texido and Klaus Rajewsky for pTV-0 DNA, J.-F. Pin for mGluR8 cDNA, K. von Figura for E14 ES cells, Pedro Grandes for histological examination of brain sections, Christoph Wiessner for help with plots and statistics, Valerie Schuler for help with Western blots, and the team of the Novartis special strain breeding facility for their support.

G.S. and T.J.B. contributed equally to this work.

Correspondence should be addressed to Herman van der Putten, Nervous System Department, Novartis Pharma AG, K125.5.13, CH-4002 Basel, Switzerland. E-mail: p_herman.van_der_putten@pharma.novartis.com.

T. Knoepfel's present address: Laboratory for Neuronal Circuit Dynamics, The Institute of Physical and Chemical Research (RIKEN) Brain Science Institute, 2-1 Hirosawa, Wako-Shi, Saitama 351-0198, Japan.

T. Bushell's present address: Imperial College, Department of Biophysics, Prince Consort Road, London SW7 2BW, UK.

C. Zhang's present address: National Eye Institute, National Institutes of Health, 10 Center Drive, Bethesda, MD 20982-1857.

R. Duvoisin's present address: Neurological Sciences Institute, Oregon Health Sciences University, Portland, OR 97201.

Copyright (C) 2001 Society for Neuroscience $\quad 0270-6474 / 01 / 218734-12 \$ 15.00 / 0$
}

mGluR8) on the basis of homology, intracellular messengers, and ligand selectivity (Conn and Pin, 1997). mGluR7 is the most highly conserved member, and its mGluR7a-isoform is distributed widely throughout the CNS (Kinzie et al., 1995; Ohishi et al., 1995; Bradley et al., 1996; Brandstaetter et al., 1996; Flor et al., 1997; Shigemoto et al., 1997). The two isoforms of the receptor are localized presynaptically, close to release sites (Bradley et al., 1996; Brandstaetter et al., 1996; Shigemoto et al., 1996; Kinoshita et al., 1998).

In recombinant expression systems L-2-amino-4-phosphonobutyrate (L-AP4), L-serine- $O$-phosphate (L-SOP), and $(R, S)$-4phosphonophenylglycine $[(R, S) \mathrm{PPG}]$ activate mGluR7 and its coupling to adenylate cyclase inhibition (Gasparini et al., 1999). Among the group III mGluRs, mGluR7 has the lowest affinity for these group III mGluR selective ligands and the endogenous ligand L-glutamate (Okamoto et al., 1994; Saugstad et al., 1994; Flor et al., 1997). In a variety of preparations L-AP4 and L-SOP reduce excitatory synaptic transmission (Koerner and Cotman, 1981; Davies and Watkins, 1982; Lanthorn et al., 1984; Anson and Collins, 1987; Bushell et al., 1995; Manzoni and Bockaert, 1995; Vignes et al., 1995; Pisani et al., 1997) via a putative presynaptic mechanism (Baskys and Malenka, 1991; Gereau and Conn, 1995) or via heterosynaptic effects on interneuron terminals (Salt and Eaton, 1995; Wan and Cahusac, 1995; Cartmell and Schoepp, 2000; Semyanov and Kullmann, 2000).

The notion that group III mGluRs are potential targets for 
novel antiepileptic drugs is supported by results in rodent models of epilepsy in which group III selective agonists showed prolonged anticonvulsant actions [L-AP4, L-SOP (Tizzano et al., 1995; Tang et al., 1997); (R,S)-PPG (Chapman et al., 1999; Gasparini et al., 1999); L-SOP (Yip et al., 2001)] and increased seizure threshold (L-AP4; Suzuki et al., 1999) or seizure latency (Thomsen and Dalby, 1998). In addition, in epilepsy the changes have been noted in the agonist sensitivity (Neugebauer et al., 2000), expression (Aronica et al., 1997; Liu et al., 2000; Yip et al., 2001), and receptor responses of group III mGluRs (Holmes et al., 1996; Neugebauer et al., 1997; Dietrich et al., 1999; Klapstein et al., 1999).

The lack of specific ligands to address mGluR7 function prompted us to generate mice lacking these receptors. A previous study that used these animals revealed deficits in taste aversion and fear responses (Masugi et al., 1999). The present study describes a role of mGluR7 in epilepsy.

\section{MATERIALS AND METHODS}

\section{Generation of $m G l u R 7^{-1-}$ mice}

A genomic fragment of the mouse mGluR7 gene was isolated from a 129SV/J $\lambda$ FIX phage library (Stratagene, La Jolla, CA) and probed with a human mGluR7 cDNA. A $2.055 \mathrm{~kb}$ NheI-NheI DNA fragment comprising the first coding exon was sequenced. It contained 405 bp of $5^{\prime}$-untranslated region (UTR; as judged by homology to rat mGluR7 cDNA), followed by codons for the first 164 amino acids of mouse mGluR7. The targeting vector was constructed by inserting a $0.6 \mathrm{~kb}$ NruI-XhoI DNA fragment (comprising 115 bp of $5^{\prime}$-UTR) $5^{\prime}$ of the pMCNeo cassette into a StuI-XhoI cleaved pTV-0 vector that contains the herpes virus thymidine kinase (TK) gene for negative selection. A 7 $\mathrm{kb}$ NheI-NheI DNA fragment comprising genomic sequences downstream of the $2.055 \mathrm{~kb}$ NheI-NheI fragment was inserted into a NheI site located between pMCNeo and pMCTK in pTV-0. Proper targeting resulted in deleting $0.585 \mathrm{~kb}$ of the first coding exon and $0.73 \mathrm{~kb}$ of the next intron of the mGlu7 gene. Embryonic day 14 (E14) embryonic stem (ES) cells [129/Ola; genotype $\mathrm{A}^{\mathrm{w}}$ (agouti), $\mathrm{c}^{\mathrm{ch}}$ (albino), p (pink-eyed dilution)] were transfected with $30 \mu \mathrm{g}$ of NotI-linearized and dideoxynucleotide-end-filled (using Klenow enzyme) targeting vector by electroporation $(250 \mathrm{~V}$ and $500 \mu \mathrm{F}$; Bio-Rad Gene Pulser, Munich, Germany). G418 (600 $\mu \mathrm{g} / \mathrm{ml})$ and Ganciclovir (Gancv; $2 \mu \mathrm{M})$ selection were applied 24 and $48 \mathrm{hr}$ later, respectively. DNA from double-resistant ES colonies was subjected to PCR analysis by using either one of two PCR primers matching sequences in the NheI-NruI fragment located just $5^{\prime}$ to, but not contained within, the targeting vector (primer-1, $5^{\prime}$ cttctgccagagctgacagtcaaag- $3^{\prime}$; primer-2, 5' -gtcagcaccaatatcgcgactcatc-3') and either one of two primers located in the neo gene (primer-3, $5^{\prime}$-gcgtgcaatccatcttgttcaatgg-3'; primer-4, 5'-gcgctgacagccggaacacg-3'). Combinations of primer-1 or primer- 2 and either one of two primers matching sequences in the coding region of the first coding exon (primer-5, 5'-gaaagtgagcgactgttcgagcg-3'; primer-6, 5'gatgttggctaccatgatggagaccg- $3^{\prime}$ ) served to detect the presence of a wildtype mGluR7 allele. Two of $112 \mathrm{G}^{2} 18^{\mathrm{r}} \mathrm{Gancv}^{\mathrm{r}}$ double-resistant ES cell clones carried a correctly targeted mGluR7 allele, as assessed by PCR and confirmed by Southern blot analysis of genomic DNA digested with NheI and NcoI, respectively, and probed with probe A (158 bp NheI-NruI fragment), probe B (0.6 kb NruI-XhoI fragment), and a neo gene probe (probe D) (Fig. 1). Southern blot analysis that used a complete mGluR7 cDNA probe (probe D) revealed no additional rearrangements in the locus (data not shown). Wild-type $(+)$ and mutant alleles $(-)$ are indicated by the presence of a $2 \mathrm{~kb}(+)$ versus $1.8 \mathrm{~kb}(-)$ NheI and a 2.5 $\mathrm{kb}(+)$ versus a $2.3 \mathrm{~kb}(-)$ NcoI DNA fragment when probed with probe A or B (Fig. 1a,b). The diagnostic sizes for a properly targeted mGluR7 allele when probed with neo (probe D) are $1.8 \mathrm{~kb}$ (NheI) and $2.3 \mathrm{~kb}$ $(\mathrm{NcoI})$. Both ES clones were used successfully to produce germ line chimeras (11 for each clone) by aggregation for 2-3 hr with $10^{6}$ ES cells per milliliter.

\section{Genotyping}

F1 mice carrying a targeted mGluR7 allele were identified by Southern blot analysis (Fig. 1b). F2 mice, derived from matings of pairs of heterozygous parents, were screened by PCR and used pairs of one of three
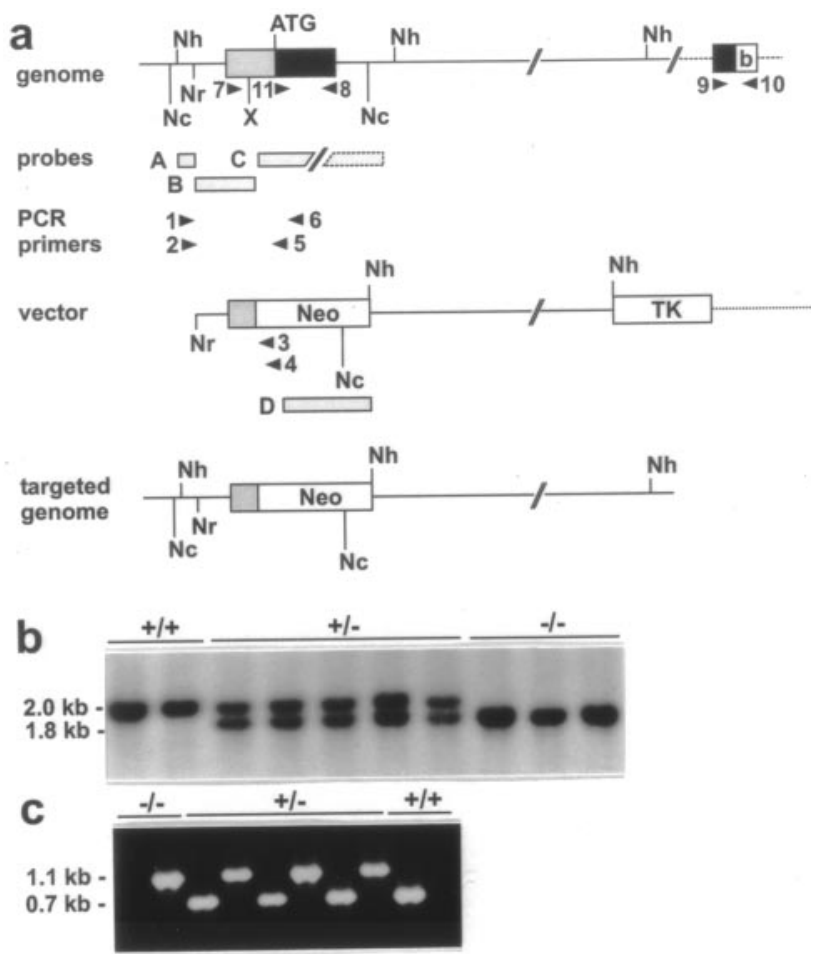

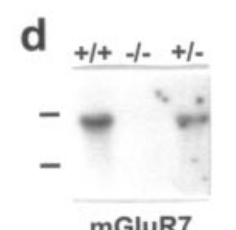

mGluR7
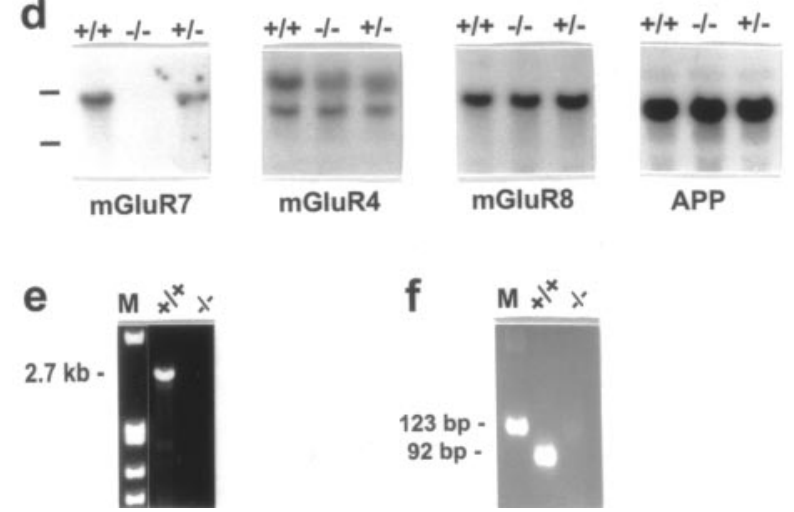

Figure 1. Targeted disruption of the mouse mGluR7 gene and its molecular analysis. $a$, Scheme of mGluR7 genomic DNA, targeting vector, disrupted gene, probes (stippled bars), and PCR primers (arrows). Neo, Neomycin resistance gene; $T K$, herpes virus thymidine kinase gene; $N h$, NheI; Nc, NcoI; Nr, NruI; X, XhoI. $b$, Southern blot analysis. Shown is the result of a representative litter of F2 mice obtained by crossing a pair of mGluR7 $7^{+/-}$F1 mice. DNA was NheI digested. Probe A was used (as shown in $a$ ). Wild-type and mutant alleles are represented by DNA fragments of 2.055 and $1.885 \mathrm{~kb}$, respectively. $c$, PCR genotyping. Example of a typical PCR result with the use of tail DNA of mGluR7 ${ }^{+/+}$, mGluR $7^{+/-}$, and mGluR $7^{-/-}$mice. Primer pairs $1+3$ yield a $1.1 \mathrm{~kb}$ product (mutant allele). Primers $7+8$ yield a $0.7 \mathrm{~kb}$ DNA fragment (wild-type allele). $d$, Northern blot analysis. Total RNA was isolated from mGluR $7^{+/+}$, mGluR7 ${ }^{+/-}$, and mGluR $7^{-/-}$brains. cDNA probes were APP, mGluR7, mGluR4, and mGluR8. $e, f$, RT-PCR. mGluR7b-specific RT-PCR products of expected sizes $2.7 \mathrm{~kb}$ (primers $11+10$ ) and $0.092 \mathrm{~kb}$ (primers $9+10$ ) were detected readily with $\mathrm{mGluR} 7^{+/+}$, but not with mGluR7 ${ }^{-/-}$, brain RNA as a template.

different forward primers $\left(5^{\prime}\right.$-cttctgccagagctgacagtcaaag- $3^{\prime}$ or $5^{\prime}$ gtcagcaccaatatcgcgactcatc- $3^{\prime}$ or $5^{\prime}$-acagtcaaagatcagactcaggggc- $3^{\prime}$ or $5^{\prime}$ ctccccataagtcagcaccaatatc- $3^{\prime}$ ) and one of two Neo-specific primers (primer-3 or primer-4) (Fig. $1 a)$ to detect the targeted allele. A combination of primer-7 (5'-gagagatggatagcaagcaagggag- $\left.3^{\prime}\right)$ and primer-8 $\left(5^{\prime}-\right.$ gtgtccctggaacaagtgtccag- $\left.3^{\prime}\right)$ served to detect the endogenous mGluR7 allele in mGluR $7^{+/+}$and $\mathrm{mGluR} 7^{+/-}$mice and to confirm its absence in 
mGluR7 ${ }^{-/-}$mice. mGluR4 mutant mice were genotyped as described previously (Pekhletski et al., 1996). mGluR8 (Duvoisin et al., 1995) mutant mice (R. Duvoisin and C. Zhang, unpublished results) were genotyped by PCR (hot-start PCR, TaqStart antibody; Promega, Madison, WI) according to the manufacturer's instructions. Annealing was 45 sec at $68^{\circ} \mathrm{C}$; primer extension was at $74^{\circ} \mathrm{C}$ for $45 \mathrm{sec}$ for 34 cycles. One combination of two primers (taactaccaggtggacgaactctc; cacaaaggtggtggcaatgattcc) was used to diagnose the endogenous mGluR8 allele in mGluR8 ${ }^{+/+}$and mGluR8 ${ }^{+/-}$mice and to confirm its absence in mGluR8 ${ }^{-/-}$mice. Another primer (taatatgcgaagtggacctgggac) combined with the first one shown above served to detect the targeted allele.

\section{$D N A$ and $R N A$ analysis}

Southern and Northern blot analyses, sequencing, PCR, and RT-PCR were performed according to standard protocols. For Northern blot analysis the following probes were used: a $3 \mathrm{~kb}$ EcoRI fragment of mouse amyloid precursor protein (APP) cDNA, a $3 \mathrm{~kb}$ HindIII fragment of human mGluR7b cDNA, a $0.57 \mathrm{~kb}$ PstI human mGluR4 cDNA fragment (encoding amino acids 520-710), and a $1.150 \mathrm{~kb}$ rat mGluR8 cDNA probe (encoding amino acids 1-350 of mGluR8). Hybridization with APP cDNA served as a control for loading equivalent amounts of total brain RNA in each lane. RT-PCR of mGluR $7^{+/+}$and $\mathrm{mGluR}^{-1-}$ brain RNA was performed with several pairs of oligonucleotide primers, including primer-1 and primer-4, primer-1 and primer-10, primer-11 and primer-10, and primer- 9 and primer-10. Primer- 9 and primer-10 were designed specifically to detect sequences comprising exon b (92 bp) encoding one of two ( $\mathrm{a}$ and b) C-terminal splice variants of mGluR7 (Flor et al., 1997).

\section{Western blot and immunocytochemical analysis}

Immunoblot procedures and immunocytochemistry were as described previously (Shigemoto et al., 1996, 1997; Kinoshita et al., 1998). Briefly, for Western blot analysis the crude membrane preparations from mouse cerebellum, hippocampus, and combined brain regions other than the cerebellum and hippocampus were separated by 7\% SDS-PAGE and transferred to polyvinylidene difluoride membranes. The membranes were reacted with an affinity-purified antibody for mGluR7a (Shigemoto et al., 1996). For detection, an alkaline phosphatase-labeled anti-rabbit secondary antibody (Chemicon, Temecula, CA) was used. For immunocytochemistry, wild-type and mGluR $7^{-1-}$ mice were anesthetized deeply and perfused transcardially with $3.5 \%$ paraformaldehyde, $1 \%$ picric acid, and $0.05 \%$ glutaraldehyde in $0.1 \mathrm{M}$ phosphate buffer (PB), $\mathrm{pH}$ 7.3. The brains were removed, cryoprotected ( $30 \%$ sucrose in $0.1 \mathrm{M} \mathrm{PB}$ overnight at $4^{\circ} \mathrm{C}$ ), and cut on a freezing microtome. The $40-\mu \mathrm{m}$-thick sections were incubated with antibodies for mGluR7a, mGluR7b, mGluR4a, or mGluR8a (Shigemoto et al., 1997; Kinoshita et al., 1998) in PBS containing $2 \%$ normal goat serum and $0.1 \%$ Triton X-100 overnight at $15^{\circ} \mathrm{C}$. After washes in PBS the sections were incubated with biotinylated goat anti-rabbit or goat anti-guinea pig IgG (Vector Laboratories, Burlingame, CA). Then the sections were washed again, reacted with the ABC kit (Vector Laboratories), and finally incubated with $0.05 \%$ diaminobenzidine and $0.0006 \%$ hydrogen peroxide.

\section{Chromosomal mapping of the $m G l u R 7$ gene}

A 129 mouse bacterial artificial chromosome (BAC) was identified and isolated by the PCR screening of a genomic 129SV DNA bank in pBeloBAC11 (Research Genetics, Huntsville, AL). The PCR primers were 7 and 8 (Fig. 1). These amplified specifically the first coding exon of the mGluR7 gene, as confirmed by sequencing. Southern blot analysis was performed with a mGluR7 cDNA probe to confirm the presence of unrearranged and diagnostic mGluR7 genomic DNA fragments. For fluorescent in situ hybridization (FISH), BAC DNA was labeled with digoxigenin-dUTP by nick translation and hybridized to normal metaphase chromosomes derived from mouse embryo fibroblasts. These analyses were performed at Genome Systems (St. Louis, MO).

\section{Electrophysiology}

Hippocampus. The 400- $\mu$ m-thick slices were prepared from 5- to 29week-old mutant mice and littermate wild types via standard procedures, as described previously (Conquet et al., 1994). Slices were submerged in a medium that comprised (in $\mathrm{mm}$ ) $124 \mathrm{NaCl}, 3 \mathrm{KCl}, 26 \mathrm{NaHCO}_{3}, 1.4$ $\mathrm{NaH}_{2} \mathrm{PO}_{4}, 1 \mathrm{MgSO}_{4}, 2 \mathrm{CaCl}_{2}$, and 10 D-glucose (bubbled with $95 \%$ $\mathrm{O}_{2} / 5 \% \mathrm{CO}_{2}, \mathrm{pH} 7.4$ ); the medium was perfused at a rate of $\sim 4 \mathrm{ml} / \mathrm{min}$ $\left(29-31^{\circ} \mathrm{C}\right)$. Extracellular recordings were obtained from stratum radia- tum or stratum pyramidale of area CA1 in response to low-frequency $(0.033 \mathrm{~Hz})$ stimulation of the Schaffer collateral-commissural pathway. For each protocol one slice was used per animal; hence $n$ values give the number of slices per mice used. Results were analyzed via Student's $t$ tests or ANOVA, with $p<0.05$ taken to indicate statistical significance. Animals were genotyped by PCR and presented to the experimenter in a randomized and blind manner.

Neocortex. Brain slice preparation and visualization of neurons in the living slice are described previously (Stuart et al., 1993; Markram et al., 1997). During recordings the slices were maintained at room temperature $\left(20-24^{\circ} \mathrm{C}\right)$ in extracellular solution consisting of (in $\left.\mathrm{mM}\right) 125 \mathrm{NaCl}$, $2.5 \mathrm{KCl}, 25$ glucose, $25 \mathrm{NaHCO}_{3}, 1.25 \mathrm{NaH}_{2} \mathrm{PO}_{4}, 2 \mathrm{CaCl}_{2}$, and $1 \mathrm{MgCl}_{2}$, pH 7.2. Whole-cell voltage recordings were performed simultaneously from two neurons with pipettes filled with (in mM) $115 \mathrm{~K}$-gluconate, 20 $\mathrm{KCl}, 4$ ATP-Mg, 10 phosphocreatine, 0.3 GTP, and 10 HEPES, pH 7.3 (310 mOsm). In synaptically connected neurons a suprathreshold intracellular stimulation of presynaptic pyramidal cells evoked depolarizing EPSPs. Presynaptic pyramidal cells were stimulated with a $10 \mathrm{~Hz}$ train of two to three suprathreshold current pulses. Typically, the trains were delivered at intervals of 5-7 sec for mGluR $7^{+/+}$mice and at $30 \mathrm{sec}$ for mGluR $7^{-1-}$ mice so that recovery from short-term modification was complete, as evidenced by the lack of systematic changes in the amplitude of the first EPSP of a train during successive trains of stimuli. For recovery from facilitation measurements, two action potentials delayed at variable time intervals $(\Delta t)$ were delivered every $30 \mathrm{sec}$ in both mGluR $7^{+/+}$and mGluR7 ${ }^{-/-}$mice. Voltage traces that are shown are averages of 50-100 sweeps. The amplitude of the first EPSP of the train is defined as the difference between the peak of the EPSP and baseline. For the second (or third) EPSP the amplitude is the difference between the peak of the EPSP and the baseline measured just before the onset of the EPSP. Stimulus delivery, data acquisition, and analyses were performed with macros in IGOR (Wavemetrics, Lake Oswego, OR).

\section{Drug administration}

Pentylenetetrazole (PTZ; Metrazol, Knoll AG, Liestal, Switzerland) was given intraperitoneally at a subthreshold dose of $40 \mathrm{mg} / \mathrm{kg}$ or at a suprathreshold dose of either 60 (in mGluR4 wild types and mutants) or $70 \mathrm{mg} / \mathrm{kg}$ (in mGluR7 and mGluR8 wild types and mutants). A dose of $40 \mathrm{mg} / \mathrm{kg}$ PTZ induced clonic or clonic-tonic seizures in $\mathrm{mGluR} 7^{-1-}$ mice only, whereas it failed to induce seizures that were visible behaviorally in mGluR4 ${ }^{+/+}$, mGluR4 ${ }^{+/-}$, mGluR4 $4^{-1-}$, mGluR $7^{++}$, mGluR $7^{+/-}$, mGluR8 ${ }^{+/+}$, mGluR8 ${ }^{+/-}$, or mGluR $^{-/-}$mice. A PTZ dose of $70 \mathrm{mg} / \mathrm{kg}$ induced clonic seizures of $\sim 5 \mathrm{sec}$ duration in at least $90 \%$ of all of the mGluR mutant and wild-type mice. Anticonvulsant drugs were given $1 \mathrm{hr}$ before PTZ. Doses used in $\mathrm{mGluR}^{+/+}$, mGluR $7^{+-}$, and $\mathrm{mGluR}^{-1-}$ mice treated with $40 \mathrm{mg} / \mathrm{kg}$ PTZ were as follows: valproate (VPA; Depakine, Sanofi, Paris, France) $(500 \mathrm{mg} / \mathrm{kg}$, p.o.), ethosuximide (ESM; Galenica, Berne, Switzerland) $(500 \mathrm{mg} / \mathrm{kg}$, p.o.), clonazepam (CZP; Rivotril, Roche, Gipf-Oberfrick, Switzerland) $(0.1 \mathrm{mg} / \mathrm{kg}$, p.o.). In the experiment in which mGluR7 mutant mice were given $70 \mathrm{mg} / \mathrm{kg}$ PTZ (see Fig. 4, black bars), at $1 \mathrm{hr}$ before PTZ the mice received placebo (water, p.o.), $500 \mathrm{mg} / \mathrm{kg} \mathrm{VPA}, 750 \mathrm{mg} / \mathrm{kg} \mathrm{ESM}$, or 1 $\mathrm{mg} / \mathrm{kg} \mathrm{CZP.} \mathrm{In} \mathrm{this} \mathrm{experiment} \mathrm{the} \mathrm{dosing} \mathrm{of} \mathrm{ESM} \mathrm{and} \mathrm{CZP} \mathrm{was}$ increased to assure maximum chances of success for counteracting the seizures in mGluR7 $7^{-1-}$ mice. Note that a dose of $70 \mathrm{mg} / \mathrm{kg}$ PTZ is far above threshold in mGluR $7^{-1-}$ mice. Bicuculline (Sigma, St. Louis, MO) was given subcutaneously at $2.5 \mathrm{mg} / \mathrm{kg}$ (mGluR7 $7^{+1-}$ and $\mathrm{mGluR}^{-1-}$ mice) or $3.5 \mathrm{mg} / \mathrm{kg}$ [Maus Auszucht Geigy (MAG) mice]. $(R, S)-4$ phosphonophenylglycine (PPG; Tocris, Bristol, UK) was dissolved in $0.9 \% \mathrm{NaCl}, \mathrm{pH}$-adjusted to $6-7$, and injected intracerebroventricularly into the mice under light Fluothane anesthesia. Injection volume was 2.5 $\mu \mathrm{l} /$ mouse. Intracerebroventricular administration of PPG in $0.9 \% \mathrm{NaCl}$ or placebo $(0.9 \% \mathrm{NaCl})$ occurred $15 \mathrm{~min}$ before PTZ was given. Doses required to evoke seizures in $\geq 80 \%$ of anesthetized (and $0.9 \% \mathrm{NaCl}$ placebo injected intracerebroventricularly) wild-type (OF-1, MAG, 129 Ola $\times$ C57BL/6) or heterozygous mGluR4, mGluR7, or mGluR8 mutant mice with different and mixed genetic backgrounds including 129Sv/ $\mathrm{J} \times \mathrm{CD}-1$ (mGluR4), 129 Ola $\times$ C57BL/6 or 129 Ola $\times$ BALB/c (mGluR7), and $129 \mathrm{~Sv} / \mathrm{J} \times \mathrm{C} 57 \mathrm{BL} / 6$ (mGluR8) were $60 \mathrm{mg} / \mathrm{kg}($ for $129 \times \mathrm{CD}-1)$ and 70 $\mathrm{mg} / \mathrm{kg}$ (for all others). Concentrations and application modes are indicated in the text and legends. All whole animal experiments were approved and conducted according to the Swiss legislation and guidelines on animal experimentation. 


\section{Seizure scoring}

Mice were considered protected from seizures and scored as such when neither clonic nor clonic-tonic seizures were observed within the first 10 min after PTZ treatment and within 30 min after bicuculline treatment. After PTZ or bicuculline treatment, clonic convulsions (myoclonic jerks, forelimb clonus) of $\sim 5 \mathrm{sec}$ duration and clonic-tonic (hindlimb extension) convulsions were scored by using behavioral monitoring, as described previously (Schmutz et al., 1990).

\section{EEG recordings}

Stainless steel screw electrodes were implanted bilaterally over the frontal and parietal cortex under isoflurane $/ \mathrm{O}_{2} / \mathrm{N}_{2} \mathrm{O}(0.5 \mathrm{l} / \mathrm{min})$ anesthesia. An indifferent electrode served as ground electrode and was positioned at bregma F1.6/12.5. All screw electrodes were connected by insulated stainless steel wiring to a four-pole socket embedded in dental cement. The electroencephalogram (EEG) that was analyzed was the differential between the frontal (bregma $F-1.0 / 13.2)$ and parietal $(F-3.0 / 13.2)$ electrodes of the same hemisphere compared with the combined reference electrodes. Bipolar leads from the mice were recorded via cables connected to a slipstring system, at the earliest $21 \mathrm{~d}$ after the operation. The behavior of the animals, which were housed singly in wooden observation cages measuring $32 \times 32 \times 40 \mathrm{~cm}$, was observed over a closed circuit TV system. The EEGs were amplified by an isolated four-channel bipolar EEG amplifier (Spectralab EEG-2104, Kilchberg, Switzerland), recorded on a thermorecorder (MTK95, Astromed), and collected on a personal computer.

\section{RESULTS}

\section{Generation of mGluR7 ${ }^{-/-}$mice}

mGluR $7^{-1-}$ mice were generated by homologous recombination (Fig. 1a). They completely lacked mGluR7 mRNA (Fig. 1d-f) in agreement with previously shown in situ hybridization results (Masugi et al., 1999). mGluR7a (Fig. $2 a-c$ ) and mGluR7b proteins (data not shown) were absent in mGluR $7^{-1-}$ mice. Brain mRNA expression levels for other group III mGluRs (mGluR4 and mGluR8) were unchanged (Fig. 1d). Gross histological abnormalities in brains of mice aged 12 weeks were not apparent, neither in standard hematoxylin and eosin-stained sections nor after immunohistology. The latter analysis included antibodies specific for the group III mGluRs mGluR4a and mGluR8a, respectively, as well as antibodies directed against other mGluR subtypes (Shigemoto et al., 1997) (data not shown).

Previous observations in 6- to 8-week-old animals from our colony also had not revealed any histological abnormalities (Masugi et al., 1999). Aging and health status of $\mathrm{mGluR} 7^{-/-}$mice did not differ from mGluR $7^{+/-}$littermates, except for a slight reduction in body weight $\left(\mathrm{mGluR}^{-1-}, 25 \pm 4 \mathrm{gm}, n=10 \mathrm{vs}\right.$ mGluR $7^{+/-}, 31 \pm 3 \mathrm{gm}, n=9$; age 4 months) and poor fecundity. There was no major morbidity except for seizures in mice aged from 10 to 12 weeks and abnormal fear and conditioned taste aversion responses in mice aged 6-8 weeks (Masugi et al., 1999).

\section{An epilepsy-prone phenotype of $\mathrm{mGluR7^{-/- }}$ mice}

Spontaneous seizures were precipitated repeatedly in standard pathogen-free (SPF) mGluR7 ${ }^{-1-}$ mice. The seizures were observed in mice aged from 10 weeks to 9 months (oldest age that was examined), but not in 6- to 8-week-old mGluR7 ${ }^{-1-}$ mice. They were never observed in mGluR $7^{+/+}$or $\operatorname{mGluR} 7^{+/-}$littermates, but an observer (unaware of the genotype) was able to detect the phenotype in 17 of $20 \mathrm{mGluR}^{-/-}$mice.

These sensory stimulus-evoked seizure episodes occurred after cage transfer. The seizures were clonic (myoclonic jerks, forelimb clonus) and sometimes tonic in nature. A lag phase of $\geq 3 \mathrm{~d}$ generally was required before $\mathrm{mGluR} 7^{-1-}$ mice showed renewed susceptibility to the same type of stimulus. Whatever its chemical nature (so far unresolved), it derived from the bedding material

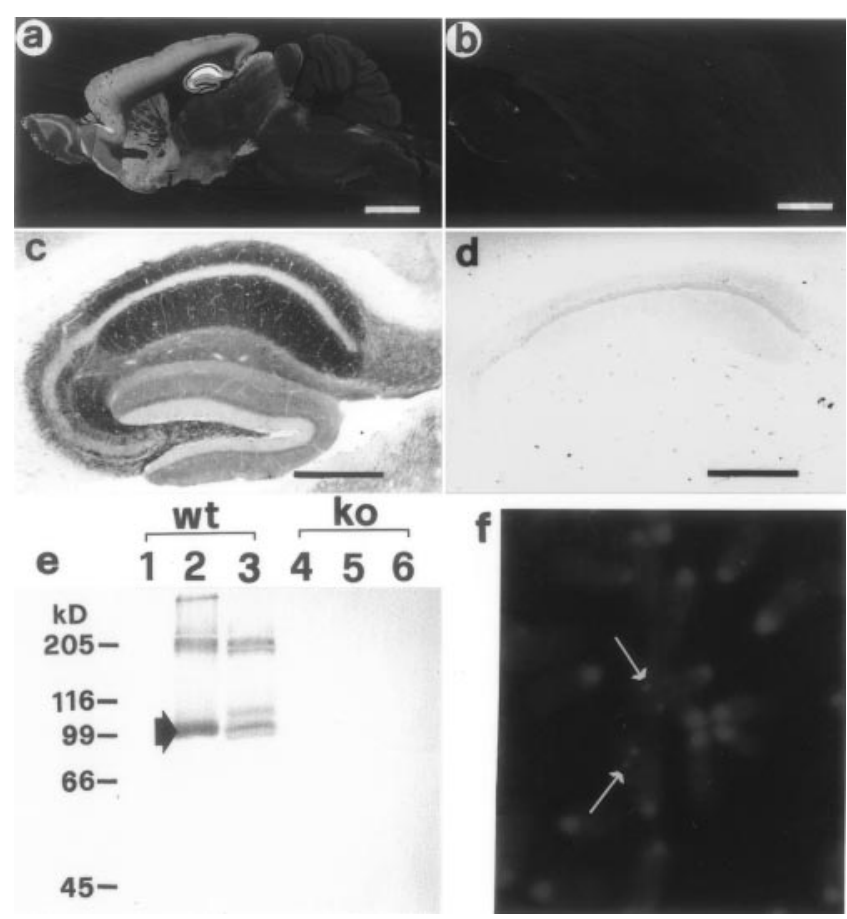

Figure 2. Lack of mGluR7 protein in mGluR $7^{-/-}$mice. $a-d$, Immunocytochemical analysis comparing reactivity of the mGluR7a-specific antibody in a brain section of a mGluR7 $7^{+/+}$mouse $(a$ and hippocampus shown enlarged in $c$ ) and lack of reactivity in mGluR $7^{-1-}$ mouse brain $(b$ and hippocampus shown enlarged in $d$ ). Scale bars: $2 \mathrm{~mm}$ (white horizontal line in $a, b$ ) and $400 \mu \mathrm{m}$ (black horizontal line in $c, d$ ), respectively. $e$, Immunoblot that uses a polyclonal rabbit mGluR7a-specific antibody (Shigemoto et al., 1996, 1997; Kinoshita et al., 1998) of homogenates of mGluR $7^{+/+}(w t)$ and $\mathrm{mGluR} 7^{-/-}(k o)$ brain regions, including cerebellum [lanes 1, 4; serving also as a negative control because this brain region contains undetectable levels of mGluR7a (Kinoshita et al., 1998)], hippocampus (lanes 2, 5), and the other combined brain regions without hippocampus and cerebellum (lanes 3, 6). The arrow indicates the position in the gel of the bulk of mGluR7a protein. $f$, Localization of the mouse mGluR7 gene to chromosome 6E1 by fluorescent in situ hybridization (FISH). White arrows indicate the position of the fluorescent signal on chromosome 6.

and, most likely, was olfactory in nature (data not shown). Its further characterization proved difficult because of the variability that was seen in seizure frequency with different batches of bedding material. Interestingly, a series of other visual, vestibular, and olfactory sensory stimuli that were tested failed to identify another stimulus that was evoking seizures (data not shown). In contrast, two chemical convulsants reproducibly evoked seizures in $\mathrm{mGluR} 7^{-/-}$mice at doses that were significantly below threshold for mGluR $7^{+/-}$and mGluR $7^{+/+}$mice (see below).

The epilepsy-prone phenotypes appeared in $\mathrm{mGluR} 7^{-1-}$ mice derived from two independently targeted ES cell clones and in mutants with different genetic backgrounds [in 1290la $\times$ C57BL/6 hybrid mice and in mice back-crossed for several generations on either C57BL/6 (F3-F14) or BALB/c (F6)].

The mouse mGluR7 gene was localized to chromosome $6 \mathrm{E} 1$ (Fig. $2 f$ ), and $70 \mathrm{~kb}$ of 1290la mouse genomic DNA was sequenced around the disrupted mGluR7 exon (S. D. McDonald, S. Goff, H. van der Putten, unpublished results). Neither procedure provided links to genes (other than the mGluR7 gene) known for predisposing to epilepsy (Allen and Walsh, 1996; McNamara and Puranam, 1998; Bate and Gardiner, 1999; Frankel, 1999), strongly 


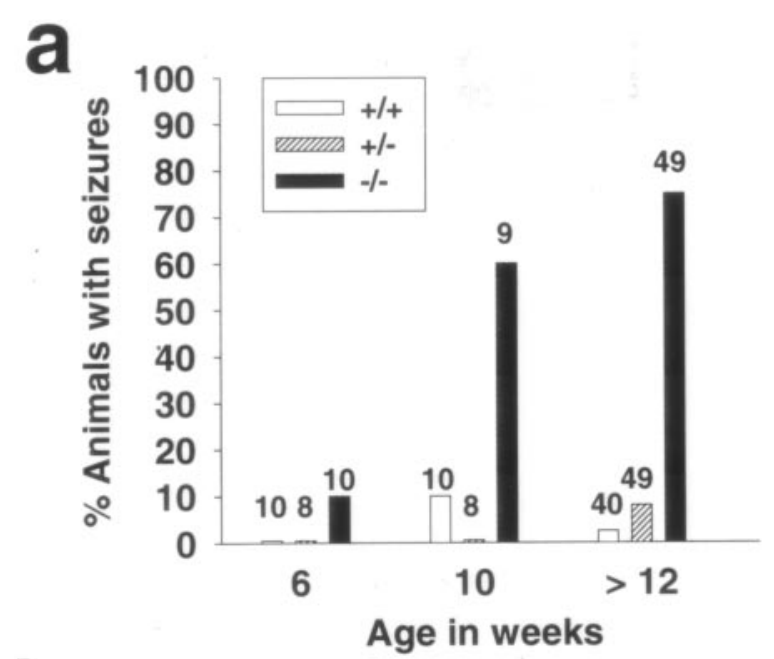

b

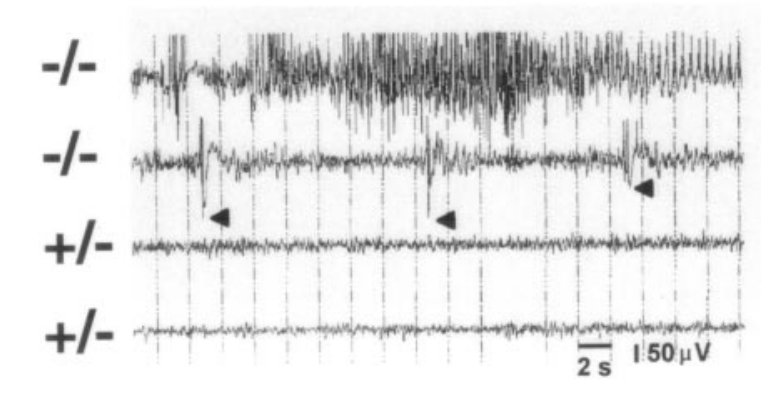

C

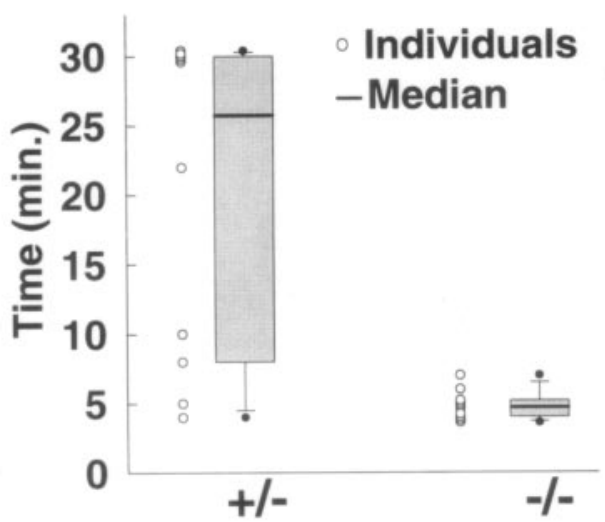

Figure 3. Increased PTZ susceptibility of $\mathrm{mGluR} 7^{-1-}$ mice to convulsant drugs. $a$, Age-dependent development of a seizure-prone phenotype in mGluR7 ${ }^{-1-}$ mice $(12901 a \times C 57 B L / 6$ and $12901 a \times B A L B / c$ mixed strain backgrounds). Groups of $8-10 \mathrm{mGluR}^{+/+}, \mathrm{mGluR} 7^{+/-}$, and mGluR $7^{-1-}$ mice aged 6,10 , and older than 12 weeks (this last group included a group of nine $\mathrm{mGluR} 7^{+/-}$and nine $\mathrm{mGluR} 7^{-1-}$ mice aged 36 weeks) were given PTZ (40 mg/kg, i.p.). Seizures (tonic in mGluR $7^{+/+}$ and mGluR $7^{+/-}$mice, and either tonic or tonic-clonic in $\mathrm{mGluR}^{-/-}$ mice) were scored behaviorally. Animals were considered protected from the convulsant effect of PTZ when neither clonic nor clonic-tonic convulsions were observed within the first 10 min after PTZ (Schmutz et al., 1990). The numbers above the bars correspond to the number of mice tested in an age group. The group aged $>12$ weeks included groups of mGluR $7^{+/+}$, mGluR $7^{+/-}$, and mGluR $7^{-/-}$mice aged $12-14,14-18$, and 22-24 weeks, respectively. It also included one group aged 36 weeks, of nine $\mathrm{mGluR} 7^{+/-}$and nine $\mathrm{mGluR} 7^{-/-}$mice, but no $\mathrm{mGluR} 7^{+/+}$mice. Of these mice, one of nine mGluR $7^{+/-}$and eight of nine $m G l u R 7^{-1-}$ showed seizures. Confidence limits in the groups of $>12$ weeks were $\pm 10 \%$ for the $\mathrm{mGluR} 7^{+/-}$groups and $\pm 15 \%$ for the $\mathrm{mGluR} 7^{-/-}$groups. suggesting that it is the homozygous mutant mGluR7 genotype that determines the epilepsy-prone phenotype in these mice.

\section{mGluR7 ${ }^{-1-}$ mice have a lower seizure threshold for convulsants}

The initial discovery of sensory stimulus-evoked seizures was not suitable as an experimental paradigm for further studies, first because of the unresolved chemical nature of the stimulus and second because of the great degree of variability in seizure incidence of $\mathrm{mGluR} 7^{-/-}$mice housed in different environments. Nevertheless, our initial findings in SPF-housed mGluR7 ${ }^{-1-}$ mice suggested a significantly reduced threshold for seizures in these mice. Our failure to identify another defined sensory stimulus that could provoke seizures reproducibly in mGluR7 $7^{-/-}$ mice prompted us to test subconvulsant doses of two drugs, pentylenetetrazole (PTZ) and bicuculline.

When administered intraperitoneally at a dose of $40 \mathrm{mg} / \mathrm{kg}$, PTZ is generally subthreshold for inducing clonic seizures in control animals. In mice 12 weeks and older, it induced seizures in 1 of $40 \mathrm{mGluR} 7^{+/+}$and in 4 of $49 \mathrm{mGluR} 7^{+/-}$mice. In contrast, it evoked seizures in the majority of $\mathrm{mGluR} 7^{-1-}$ littermate mice ( 43 of $58 ; 74 \%$ ) (Fig. $3 a$ ). Note that all of these mice were aged 10 weeks or older before testing to assure development of the epilepsy-prone phenotype in $\mathrm{mGluR} 7^{-/-}$mice. The PTZevoked seizures in mGluR $7^{-1-}$ mice were frequently both clonic and tonic in nature and were followed by death $(>50 \%$ of the mice). For comparison, in $\mathrm{mGluR} 7^{+/+}$and $\mathrm{mGluR} 7^{+/-}$mice, 70 $\mathrm{mg} / \mathrm{kg}$ PTZ was required to produce seizures that consistently were generally only clonic in nature.

In mice aged 6 weeks the PTZ $(40 \mathrm{mg} / \mathrm{kg})$ failed to evoke seizures in a statistically significant manner (Kruskal-Wallis oneway ANOVA on ranks, $p=0.407)$. In only 1 of $10 \mathrm{mGluR7}^{-/-}$ mice were the seizures observed. When this mouse was eliminated from the group and the others were retested $(40 \mathrm{mg} / \mathrm{kg}$ PTZ) at age 10 weeks, six of nine $m G l u R 7^{-/-}$mice showed clonic seizures. In parallel and at both ages only one mouse of two groups of $n=10 \mathrm{mGluR} 7^{+/+}$mice (MAG; parental strains, NIH and Maus Inzucht Geigy) and no mGluR7 $7^{+/-}$mice showed seizures ( $p=0.003$, Kruskal-Wallis one-way ANOVA on ranks revealed a significant difference among the genotypes; $p=0.023$, Mann-Whitney rank-sum test for $+/-$ vs $-/-)$.

Five different groups $(n=9-10$ per group and genotype) of

$\leftarrow$

$b$, Electrographic seizures in mGluR7 $7^{-1-}$ mice. EEGs recorded for 1 week and for $24 \mathrm{hr}$ continuously in freely moving mGluR7 ${ }^{-1-}$ and mGluR7 ${ }^{+/-}$mice (each group $n=4$, aged 16-20 weeks) revealed no spontaneous epileptiform activity (data not shown). After the 1 week of recording the same mice were given $40 \mathrm{mg} / \mathrm{kg}$ PTZ, and the seizures were recorded by behavior as well as by electroencephalography. For each genotype group two representative EEG recordings from two different individuals are shown, starting at $210 \mathrm{sec}$ after PTZ injection. The top two traces are from two different mGluR7 ${ }^{-1-}$ mice; the bottom two traces are from two different mGluR $7^{+/-}$mice. The first mGluR $7^{-1-}$ mouse (top trace) had tonic-clonic seizures; the second mGluR $7^{-1-}$ mouse (second trace from top) had clonic seizures manifested behaviorally as body jerks (arrowheads in EEG). None of the mGluR $7^{+/-}$mice (bottom two traces) showed epileptiform activity. Time scale is shown in seconds, and amplitude is in microvolts. $c$, Increased susceptibility to seizures for the $\mathrm{GABA}_{\mathrm{A}}$ receptor antagonist bicuculline, as shown by comparing two groups of $10 \mathrm{mGluR}^{+/-}$and mGluR7 ${ }^{-1-}$ mice (aged $14-16$ weeks) that were given $2.5 \mathrm{mg} / \mathrm{kg}$ bicuculline. Seizures were scored behaviorally. Plotted is the time in minutes for individual animals to develop clonic seizures. Observation time was $30 \mathrm{~min}$ after drug application, and mice plotted at this value were without seizures. 
mGluR7 ${ }^{-/-}$, $\mathrm{mGluR}^{+/+}$, and $\mathrm{mGluR} 7^{+/-}$mice were tested at ages $12-36$ weeks, and the overall results are shown (Fig. $3 a$ ). One of $40(2.5 \%) \mathrm{mGluR}^{+/+}$and 4 of $49(8 \%) \mathrm{mGluR}^{+/-}$mice showed seizures (clonic only). In contrast, 37 of $49(75 \%)$ mGluR $7^{-1-}$ mice showed clonic seizures that often (in $>60 \%$ of these mice) progressed to tonic seizures. Often, $\mathrm{mGluR} 7^{-/-}$mice with tonic seizures died. Statistical significance for the results in the groups aged $>12$ weeks is given by pairwise comparison of the genotype groups with the Mann-Whitney rank-sum test ( $p=<0.001$ for the $+/+$ vs $-/-$ and the $+/-$ vs $-/-$ groups; $p>0.05$ and no statistical significance when comparing $+/+$ and $+/-$ groups). At age 36 weeks, differences in PTZ sensitivity remained statistically significant ( $p=0.002$, Mann-Whitney rank-sum test; comparison of a single group of nine mGluR $7^{+/-}$ and nine $\mathrm{mGluR} 7^{-/-}$mice).

Spontaneous epileptiform activity was not detected during 1 week of continuous ( $24 \mathrm{hr} / \mathrm{d})$ EEG recordings by using bilaterally implanted frontal and parietal electrodes in mGluR7 ${ }^{+/-}(n=4)$ and $\mathrm{mGluR7}^{-1-}(n=4)$ mice. A subsequent injection of PTZ (40 $\mathrm{mg} / \mathrm{kg}$, i.p.) rapidly triggered epileptiform discharges and seizure manifestations that were specific to the mGluR $7^{-1-}$ mice. The same dose of PTZ injected into the $\mathrm{mGluR} 7^{+/-}$mice triggered no detectable discharges (Fig. $3 b$ ), indicating a significantly reduced threshold for PTZ-induced discharges and seizures in the mGluR7 ${ }^{-/-}$mice.

Susceptibility to seizures also was increased for the competitive $\mathrm{GABA}_{\mathrm{A}}$ receptor antagonist bicuculline. Two groups of 10 mGluR7 ${ }^{+/-}$and mGluR7 ${ }^{-/-}$mice (aged $14-16$ weeks) were given $2.5 \mathrm{mg} / \mathrm{kg}$ bicuculline subcutaneously and were observed for $30 \mathrm{~min}$. The latency to first seizure was plotted (Fig. $3 c$ ) for individual animals showing clonic seizures. Mice plotted at the 30 min value were without seizures. The median (horizontal bar in bold) for each group was $4 \mathrm{~min}$ (mGluR7 ${ }^{-1-}, 25 \%$ at $4 \mathrm{~min}$ and $75 \%$ at $5 \mathrm{~min}$ ) versus $26 \mathrm{~min}\left(\mathrm{mGluR} 7^{+/-}, 25 \%\right.$ at $8 \mathrm{~min}$ and $75 \%$ at $30 \mathrm{~min}$ ), respectively (Mann-Whitney rank-sum test, $p=$ $0.003)$. For reference, nine of nine $\mathrm{mGluR} 7^{+/+} \mathrm{MAG}$ mice treated with the same lot, and for MAG mice a standard suprathreshold dose of $3.5 \mathrm{mg} / \mathrm{kg}$ bicuculline, showed clonic seizures with a mean onset time of $3.2 \mathrm{~min}$ (data not shown).

\section{Effects of standard anticonvulsant drugs}

Three widely used mechanistically different antiepileptic drugs (White, 1997), ethosuximide (ESM), clonazepam (CZP), and valproate (VPA), were tested in $\mathrm{mGluR} 7^{-1-}$ mice for protection from PTZ-evoked seizures (Fig. 4).

First (Fig. 4a, b, gray bars), three groups of $10 \mathrm{mGluR}^{+/-}$and $10 \mathrm{mGluR}^{-1-}$ mice (all aged 14-20 weeks) received pretreatment ( $1 \mathrm{hr}$ before $40 \mathrm{mg} / \mathrm{kg}$ PTZ, i.p.) with an antiepileptic drug (CZP, $0.1 \mathrm{mg} / \mathrm{kg}$, p.o.; ESM, $500 \mathrm{mg} / \mathrm{kg}$, p.o.; VPA, $500 \mathrm{mg} / \mathrm{kg}$, p.o.). In parallel, another group of $10 \mathrm{mGluR} 7^{+/-}$and 10 mGluR $7^{-1-}$ mice and, in addition, $10 \mathrm{mGluR} 7^{+/+}$wild-type (MAG) mice received a placebo (Methocel as reference for ESM and CZP; water compared with VPA). At $1 \mathrm{hr}$ after placebo or anticonvulsant drug treatment all of the mice were given PTZ (40 $\mathrm{mg} / \mathrm{kg}$, i.p.). PTZ induced seizures in $60-90 \%$ of each of the placebo-treated mGluR $7^{-1-}$ groups $(n=3 \times 10)$, but not in any of the placebo-treated mGluR $7^{+/-}(n=3 \times 10)$ or $\operatorname{mGluR} 7^{+/+}$ (MAG; $n=3 \times 10$ ) mice. ESM, CZP, and VPA protected $100 \%$ of the $\mathrm{mGluR}^{-/-}$mice ( $n=10$ per group and compound) from PTZ-induced seizures (statistical significance for each drugtreated versus placebo group is given by $p<0.05$, Mann-Whitney rank-sum test).
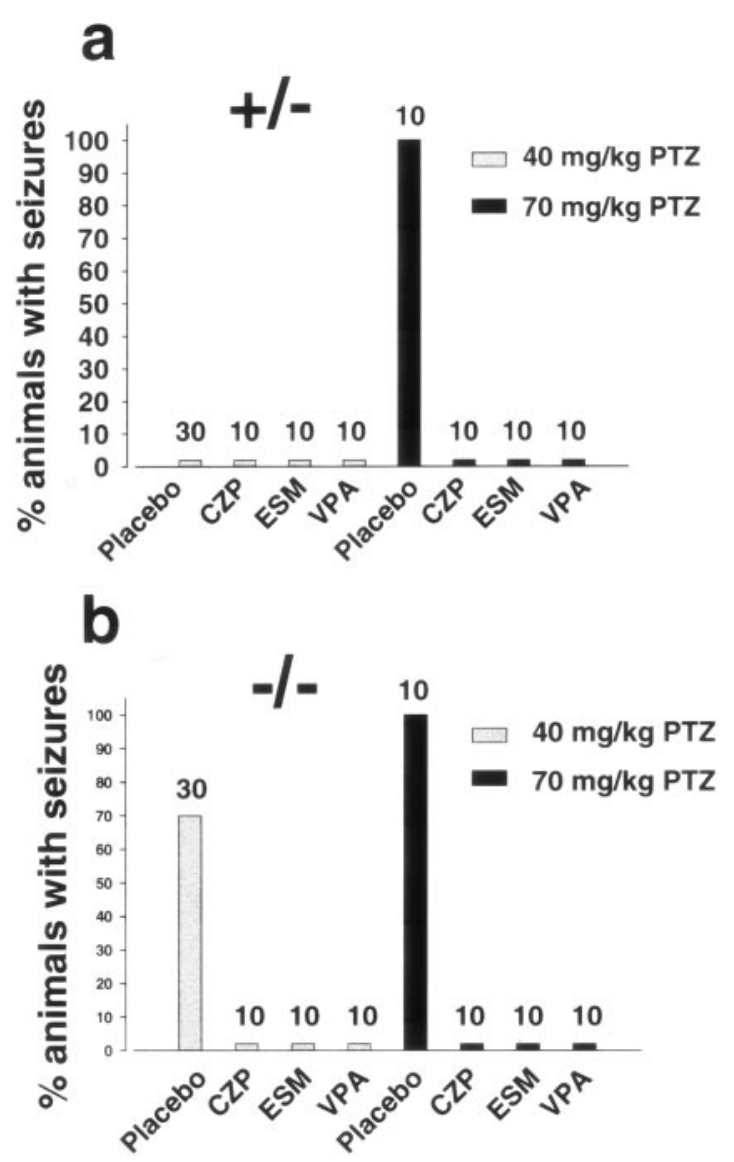

Figure 4. The actions of three standard anticonvulsants are unimpaired in mGluR $7^{-1-}$ mice. $a$, $b$, Plotted is the percentage of mice with seizures, scored behaviorally, for a period of $10 \mathrm{~min}$ in response to PTZ (40 or 70 $\mathrm{mg} / \mathrm{kg}$ ) given intraperitoneally. The number above each bar indicates the group size. The gray bars represent groups of mice given $40 \mathrm{mg} / \mathrm{kg}$ PTZ that were pretreated $1 \mathrm{hr}$ before PTZ with either placebo (Methocel in two groups of $n=10$ per genotype and as reference for ESM and CZP; water was the placebo in one group of $n=10$ per genotype and compared with VPA) or anticonvulsant (0.1 mg/kg CZP, p.o.; $500 \mathrm{mg} / \mathrm{kg}$ ESM, p.o.; or $500 \mathrm{mg} / \mathrm{kg}$ VPA, p.o.). The black bars in $a$ and $b$ represent groups of 10 mice per genotype that had received PTZ (70 mg/kg, i.p). At $1 \mathrm{hr}$ before PTZ all of the mice in a group had received the placebo (water, p.o.), CZP (1 mg/kg, p.o.), ESM (750 mg/kg, p.o.), or ESM (500 mg/kg). Unlike in mGluR7 $7^{-1-}$ mice $(b)$, the $40 \mathrm{mg} / \mathrm{kg}$ PTZ dose is below threshold for inducing seizures in $\operatorname{mGluR} 7^{+/}(a)$ and wild types (mGluR $7^{+/+}$mice; data not shown). Therefore, mGluR $7^{+/-}$mice displayed no seizures, regardless of pretreatment with placebo or anticonvulsant. In contrast, $70 \%$ of all mGluR $7^{-1-}$ mice showed clonic or clonic-tonic seizures when given placebo $(b)$. The injection of $70 \mathrm{mg} / \mathrm{kg}$ PTZ evoked seizures (clonic in mGluR $7^{+/-}$and $\mathrm{mGluR} 7^{+/+}$mice; clonic or clonic-tonic in mGluR $7^{-1-}$ mice) in at least $90 \%$ of all placebo-treated mice, regardless of their mGluR7 genotype. CZP, ESM, and VPA fully protected from PTZ-induced clonic seizures in $\mathrm{mGluR} 7^{+/-}$(black bars in a) and mGluR7 $7^{+/+}$mice (data not shown) as well as from PTZ-induced clonic or clonic-tonic seizures in $\mathrm{mGluR} 7^{-1-}$ mice.

All three anticonvulsant drugs also provided protection in mGluR7 ${ }^{-1-}$ mice when challenged with $70 \mathrm{mg} / \mathrm{kg}$ PTZ (Fig. $4 a, b$, black bars), a dose that evoked clonic seizures in at least $90 \%$ all $\mathrm{mGluR}^{+/-}$(Fig. $4 b$ ) and $\mathrm{mGluR} 7^{+/+}$mice (data not shown). In this experiment we increased the dose of ESM (to 750 instead of $500 \mathrm{mg} / \mathrm{kg}$ ) and CZP (to $1 \mathrm{mg} / \mathrm{kg}$ instead of 0.1 $\mathrm{mg} / \mathrm{kg})$. VPA dosing $(500 \mathrm{mg} / \mathrm{kg})$ was not increased, because this can cause lethality in mice. Given that all three anticonvulsants protected mGluR7 ${ }^{-1-}$ mice from either 40 or $70 \mathrm{mg} / \mathrm{kg}$ PTZ- 
induced seizures, we conclude that mGluR7 receptors do not contribute significantly to mechanisms underlying the action of these antiepileptics.

\section{Anticonvulsant effects of PPG are diminished greatly in mGluR7 ${ }^{-1-}$ mice}

The group III mGluR selective agonist PPG has shown potent and sustained anticonvulsant actions in several rodent models of epilepsy (Chapman et al., 1999; Gasparini et al., 1999). Therefore, we compared its anticonvulsant action against PTZ-evoked seizures in $\mathrm{mGluR} 7^{-1-}$ mice and two other mGluR group III mutant mice, the mGluR $4^{-1-}$ and mGluR $8^{-1-}$ mutants. All of the mice used in these experiments were aged from 12 to 20 weeks before testing to allow for development of the seizureprone phenotype in the mGluR $7^{-1-}$ mice. Also, we tested different doses of PTZ to determine, in each of the strain backgrounds of the different mutants, a dose that evoked clonic convulsions in $80 \%$ or more of the mice under the experimental conditions that were used, i.e., light Fluothane anesthesia, intracerebroventricular injection of placebo $(0.9 \% \mathrm{NaCl})$, followed 15 min later by intraperitoneal injection of PTZ. Determining these experimental conditions was necessary because PPG is not active when given systemically (Gasparini et al., 1999), and, when given intracerebroventricularly, it requires brief anesthesia that increases PTZ thresholds (data not shown). In addition, PTZ thresholds depend on multiple chromosomal loci that differ between mouse strains (Kosobud et al., 1992; Ferraro et al., 1999), and mGluR4 ${ }^{-1-}$, mGluR7 ${ }^{-1-}$, and mGluR $8^{-1-}$ mutant mice have mixed and different genetic contributions from a number of strains. Accordingly, the PTZ doses required under our experimental conditions were $60 \mathrm{mg} / \mathrm{kg}$ in mGluR4 mutants (129Sv/ $\mathrm{J} \times \mathrm{CD} 1)$ and $70 \mathrm{mg} / \mathrm{kg}$ in mGluR7 [129Ola $\times$ C57BL $/ 6$ and $(129$ Ola $\times$ C57BL/6) $\times$ BALB/c] and mGluR8 [(129×C57BL/ 6) $\times$ C $57 \mathrm{BL} / 6]$ mutants.

Next, dose responses for PPG (see Gasparini et al., 1999) (data not shown) in the different heterozygous mGluR mutant mice revealed that $634 \mathrm{nmol}$ intracerebroventricularly $(2.2 \mathrm{mg} / \mathrm{kg})$ could protect $\geq 70 \%$ of the different heterozygous mutant mice from seizures induced by PTZ. This protective effect of PPG was reduced dramatically in mGluR $7^{-/-}$, but not in $\mathrm{mGluR} 4^{-/-}$and mGluR $8^{-1-}$, mice (Fig. 5). The loss of the anticonvulsant activity of PPG in mGluR7 ${ }^{-1-}$ mice treated with $70 \mathrm{mg} / \mathrm{kg}$ PTZ was specific to PPG because CZP, ESM, and VPA provided complete protection in both $\mathrm{mGluR} 7^{+/-}$and $\mathrm{mGluR} 7^{-/-}$mice challenged with this dose of PTZ (Fig. 4a,b; $70 \mathrm{mg} / \mathrm{kg}$ PTZ dose results are represented by black bars in the histograms).

\section{Altered excitability in hippocampal slices}

Because of similarities between seizures observed in mGluR7 ${ }^{-1-}$ mice and those known to involve limbic systems, we examined electrophysiological responses in hippocampal slices. We focused primarily on synaptic transmission in the CA1 region because CA3-derived Schaffer collateral-commissural terminals are rich in mGluR7a (Shigemoto et al., 1996, 1997) (Fig. 2c) and CA3 is a major trigger region for discharge activity that can propagate to CA1 and beyond in different models of epileptic discharge (Wong and Traub, 1983; Barbarosie and Avoli, 1997). Input-output curves relating the initial slope of the field EPSP to either stimulus intensity or presynaptic fiber volley amplitude revealed no significant differences between $\mathrm{mGluR}^{-/-}$and $\operatorname{mGluR} 7^{+/+}$

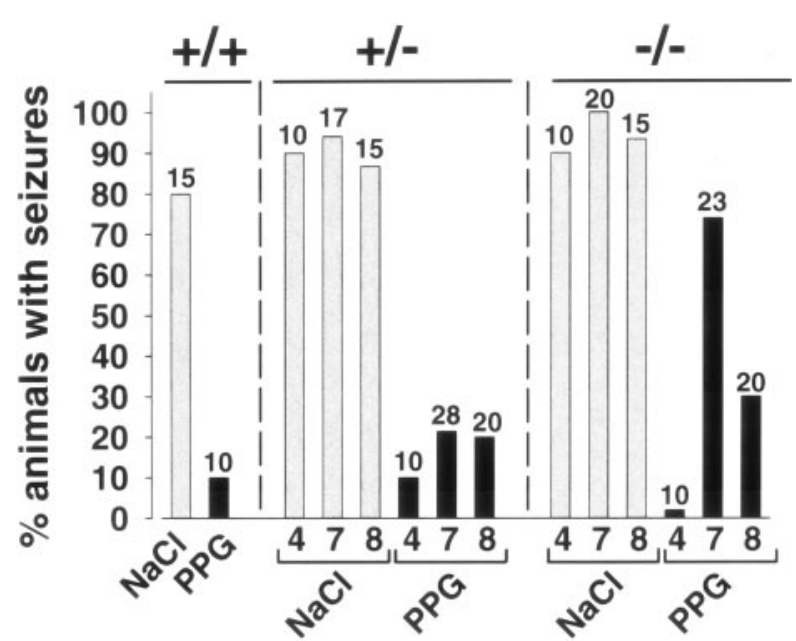

Figure 5. Greatly reduced anticonvulsant action of PPG in $\mathrm{mGluR}^{-/-}$ mice. Shown are the protective effects of $634 \mathrm{nmol}$ of PPG intracerebroventricularly (black bars) versus $0.9 \% \mathrm{NaCl}$ (gray bars) in mGluR7 $7^{+/+}$ mice $(+/+)$ and the different $\mathrm{mGluR}^{+/-}$and $\mathrm{mGluR}^{-/-}$mutant mice as indicated by the numbers 4,7 , and 8 on the horizontal axis (all mice aged $\geq 12$ weeks). PPG was given intracerebroventricularly 15 min before the intraperitoneal injection of PTZ $[60 \mathrm{mg} / \mathrm{kg}$ in mGluR4 mutants; 70 $\mathrm{mg} / \mathrm{kg}$ in all wild types $(+/+)$ and other $\mathrm{mGluR}$ mutants]. Seizures were scored behaviorally for a period of $10 \mathrm{~min}$ (Schmutz et al., 1990). The numbers above the bars indicate the number of mice per group. The protective effects of PPG versus $\mathrm{NaCl}$ were $78 \%$ (22 of 28) versus $6 \%$ (1 of 17) in mice with one mutant mGluR7 allele and $26 \%$ (6 of 23) versus $0 \%$ ( 0 of 20$)$ in mice with two mutant mGluR7 alleles. Unlike a comparison of the protective effect of PPG between $\operatorname{mGluR} 7^{+/-}$and mGluR7 ${ }^{-1-}$ mice, there were no statistically significant differences in the protective action of PPG when $\mathrm{mGluR}^{+/-}, \mathrm{mGluR} 4^{-/-}, \mathrm{mGluR}^{+/-}$, and $\mathrm{mGluR} 8^{-1-}$ groups were compared (all $p>0.05$ ). Confidence limits for the groups $n>10$ were $\pm 10 \%$. For PPG versus $\mathrm{NaCl}$ comparisons in all groups, $p$ values were $<0.001$ (Kruskal-Wallis one-way ANOVA on ranks, Dunn's test). Other values were $\mathrm{mGluR} 7^{-/-}$versus $\mathrm{mGluR} 7^{+/+}$ (wild type), $p=0.004 ; \mathrm{mGluR}^{-/-}$versus mGluR4 ${ }^{-1-}, p<0.001$; mGluR $^{-/-}$versus mGluR8 ${ }^{-1-}, p=0.014$ (Mann-Whitney rank-sum tests).

mice (Fig. 6a,b). Paired pulse facilitation was also similar between groups. For example, with an interpulse interval of $50 \mathrm{msec}$ the facilitation ratios in CA1 were $1.45 \pm 0.04(n=9)$ and $1.49 \pm 0.03$ $(n=9)$, respectively.

Next, we determined whether hippocampal slices from mGluR $7^{-1-}$ mice were more excitable when the stimulus intensity was increased to evoke a population spike and activate GABAergic synapses polysynaptically (Fig. $6 c, d$ ). In the absence of PTZ a very small secondary population spike was apparent in 8 of 11 slices from null mice $(0.067 \pm 0.020$ of the first population spike) but only in 1 of 10 slices from controls $(0.009 \pm 0.011$ of the first population spike; Student's $t$ test, $p<0.05)$. Thus, slices prepared from $\mathrm{mGluR} 7^{-1-}$ mice were slightly more excitable under control conditions.

Given the lower seizure threshold of $\mathrm{mGluR} 7^{-/-}$mice to PTZ, we examined the effects of PTZ on synaptic transmission in CA1. PTZ caused a reduction in synaptic inhibition, manifest as a concentration-dependent appearance of multiple population spikes in both mGluR $7^{-1-}$ and wild-type mice (Fig. $6 c, d$ ). The effect was such that differences in excitability between mGluR7 ${ }^{-1-}$ and wild-type littermates, observed in the absence of PTZ, were no longer evident when higher concentrations of PTZ (1-4 mM) were used. 


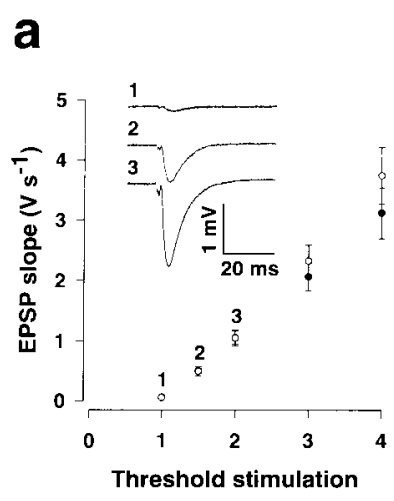

b

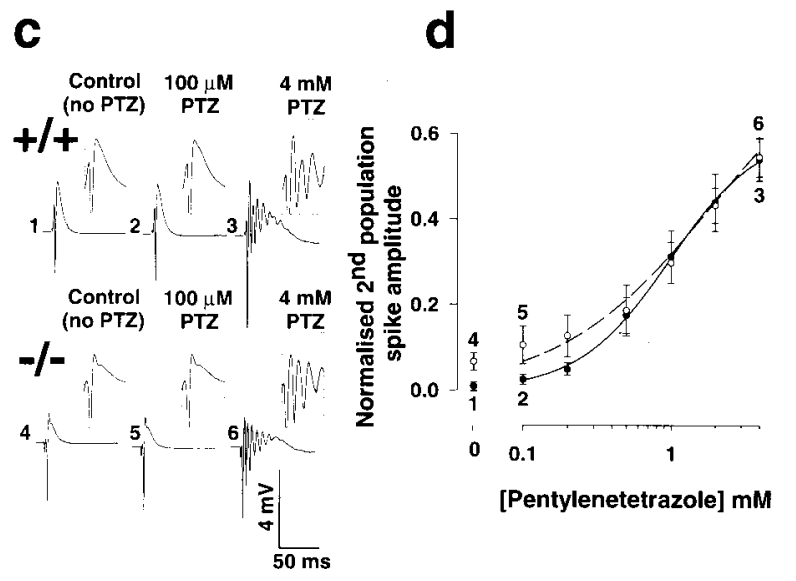

Figure 6. Increased excitability in the CA1 region of hippocampal slices from mGluR $7^{-1-}$ mice. $a$, Plotted is the slope of the field EPSP, recorded in stratum radiatum, versus relative stimulus strength, expressed as a function of the threshold intensity (i.e., the intensity at which a response is just detectable in single records) for $\mathrm{mGluR} 7^{-/-}$and $\mathrm{mGluR} 7^{+/+}$mice. The traces are averages of successive responses from a typical mGluR $7^{-1-}$ mouse at the times indicated (1-3); the input-output curves show no significant difference in excitatory synaptic transmission between wild-type $(n=14)$ and null mice $(n=12)$. $b$, Input-output curve, relating the slope of the field EPSP to the presynaptic fiber volley amplitude. $c$, Examples of somatic field recordings from wild-type (1-3) and mGluR $7^{-1-}$ mice (4-6) to illustrate the effects of increasing concentrations of PTZ. The insets are a magnification $(2.5 \times)$ of the windows shown in $c 1$ and $c 4$ to illustrate the generation of multiple population spikes on a faster time base. Field potentials were recorded from stratum pyramidale and input-output curves that were constructed. Then the stimulus intensity was set at that which produced a first population spike of $\sim 30 \%$ of the maximum, and PTZ was applied sequentially in increasing concentrations. $d$, Pooled data for 10 wild-type and $11 \mathrm{mGluR}^{-1-}$ mice (aged between 8 and 29 weeks) of the amplitude of the second population spike, expressed as a function of the primary population spike, versus PTZ concentration. Open symbols, mGluR $7^{-1-}$ mice; filled symbols, littermate wild types, throughout.

\section{Altered frequency-dependent facilitation in mGluR7 ${ }^{-1-}$ mice}

To investigate mechanisms that might underlie the changes in excitability, we turned to a different slice preparation and studied transmission between synaptically coupled pyramidal neurons and bitufted interneurons in layer $2 / 3$ of the neocortex. This synapse contains a high density of presynaptic mGluR receptors, including mGluR7 (Shigemoto et al., 1996), and it demonstrates frequency-dependent facilitation (Reyes et al., 1998), which is believed to arise from the elevation of $\mathrm{Ca}^{2+}$ at the presynaptic release site (Zucker, 1994; Fisher et al., 1997; Rozov et al., 2001).

As seen in the hippocampus (see paired pulse data in previous section), facilitation in response to brief trains of two or three
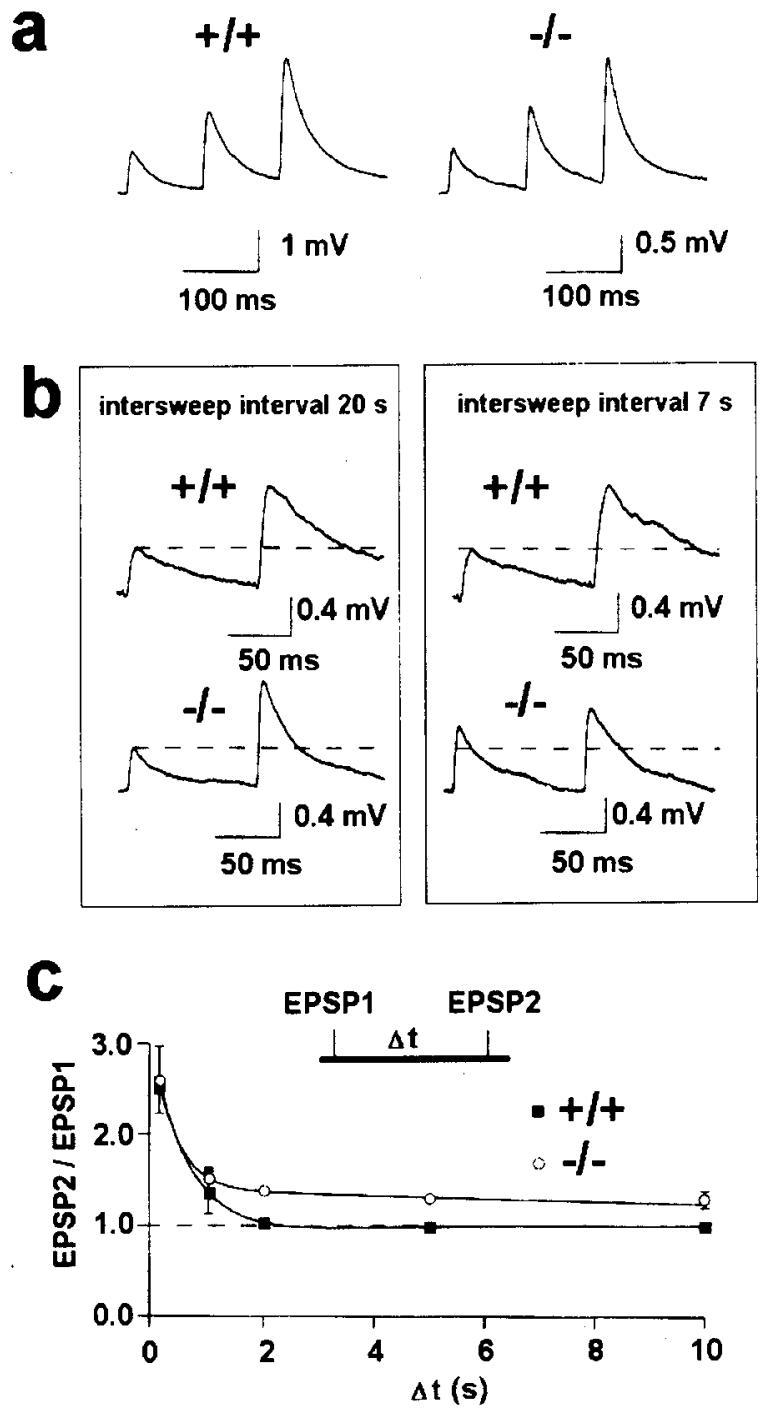

Figure 7. Altered recovery from paired pulse facilitation in $\mathrm{mGluR} 7^{-1-}$ mice. Simultaneous whole-cell paired recordings from synaptically connected pyramidal and bitufted neurons in layer $2 / 3$ of GluR $^{+/+}(n=9)$ and mGluR7 ${ }^{-1-}(n=7)$ mice (P14; neocortex). $a$, Averaged EPSPs $(n=$ $50-100)$ recorded from bitufted neurons of mGluR7 ${ }^{+/+}$and $\mathrm{mGluR}^{-/-}$ mice in response to a train of three action potentials evoked in a projecting pyramidal neuron at $10 \mathrm{~Hz}$. Time intervals between trains (intersweep intervals) were $30 \mathrm{sec}$ in both cases. $b$, Averaged EPSPs of 50-100 sweeps recorded from bitufted neurons in response to two action potentials that were evoked in pyramidal neurons with a $100 \mathrm{msec}$ time interval. The difference between the left and right traces is the intersweep interval (time between subsequent pairs of action potentials). For the left traces it was 20 $\mathrm{sec}$, and for the right traces it was $7 \mathrm{sec}$, as indicated above the traces. The top traces in each box represent recordings from $\mathrm{mGluR} 7^{+/+}$mice, and the bottom traces are from mGluR7 $7^{-1-}$ mice. For each genotype the representative recordings that are shown (i.e., averaged EPSPs of 50-100 sweeps) are from the same bitufted neuron. $c$, Time course of recovery from facilitation measured in bitufted neurons. The ratios of the mean EPSP amplitudes (EPSP2/EPSP1) were plotted against $\Delta t$.

action potentials (at $10 \mathrm{~Hz}$ in this preparation) was similar in mGluR $7^{-/-}$and mGluR7 ${ }^{+/+}$mice, provided that the intersweep interval time was sufficiently long (Fig. $7 a$; in both cases intersweep interval was $30 \mathrm{sec}$ ). However, a marked difference was observed among mice when recovery from facilitation was studied. In one set of experiments paired pulses were delivered with a fixed interpulse interval of $100 \mathrm{msec}$, but the interval between 
paired pulses (intersweep interval) was varied between 5 and 30 sec (Fig. 7b). Averaged EPSPs recorded from the same bitufted neuron (see left trace in $a$ ) in a mGluR $7^{+/+}$mouse in response to a train $(10 \mathrm{~Hz})$ of two action potentials delivered at $20 \mathrm{sec}$ (left) and $7 \mathrm{sec}$ (right) intersweep intervals shows that the amplitude of the first EPSP (EPSP1) and the paired pulse facilitation ratio (EPSP2/EPSP1) were similar at 20 and 7 sec intersweep interval times. In this mouse the EPSP1 amplitudes were 0.46 and 0.49 $\mathrm{mV}$, and EPSP2/EPSP1 ratios were 2.24 and 2.12 at the 20 and 7 sec intersweep intervals, respectively. In the $\mathrm{mGluR}^{-/-}$mouse (bottom traces) the EPSP1 amplitude increased from $0.39 \mathrm{mV}$ at the $20 \mathrm{sec}$ intersweep interval to $0.75 \mathrm{mV}$ at the $7 \mathrm{sec}$ intersweep interval, and the EPSP2/EPSP1 ratio decreased from 2.61 to 1.28 at the 20 and $7 \mathrm{sec}$ intersweep intervals, respectively. Overall, in this set of experiments the EPSP1 amplitudes with the $7 \mathrm{sec}$ intersweep interval were $100 \pm 12 \%$ of those measured with 20 sec interval, and the EPSP2/EPSP1 ratios were $2.51 \pm 0.28$ and $2.56 \pm 0.47$ at the 20 and $7 \mathrm{sec}$ intersweep intervals, respectively, in $\operatorname{mGluR} 7^{+/+}$mice $(n=4)$. In the $\operatorname{mGluR} 7^{-1-}$ group the EPSP1 amplitudes with the $7 \mathrm{sec}$ intersweep interval were $59.7 \pm$ $28.3 \%$ larger than those recorded at the $20 \mathrm{sec}$ interval. EPSP2/ EPSP1 ratios decreased from $2.87 \pm 0.88$ to $1.27 \pm 0.03$ for 20 and $7 \mathrm{sec}$, respectively. In summary, in $\mathrm{mGluR} 7^{+/+}$mice the facilitation recovered within 5-7 sec, as observed previously with rats (Reyes et al., 1998). In contrast, in $\mathrm{mGluR} 7^{-1-}$ mice full recovery from facilitation required $20-30 \mathrm{sec}$.

In a separate set of experiments the time course of recovery from facilitation was calculated by using a repeated paired pulse protocol. Every $30 \mathrm{sec}$ a train of two action potentials (indicated as EPSP1 and EPSP2) was evoked. One of several different time intervals was chosen $(\Delta t=0.1,1,2,5$, and $10 \mathrm{sec}$, respectively) between action potentials 1 and 2 , and 50-100 individual sweeps were averaged for each $\Delta t$. The intersweep intervals thus were kept constant at $30 \mathrm{sec}$ in all of these experiments to allow the facilitation to recover in $\mathrm{mGluR} 7^{-1-}$ mice also. The plot shows the summarized results of delivering paired pulses with the different interpulse intervals. In $\mathrm{mGluR} 7^{+/+}$mice the recovery from facilitation was evident by $2 \mathrm{sec}$, whereas even after $10 \mathrm{sec}$ the recovery in $\mathrm{mGluR} 7^{-/-}$mice was still incomplete (Fig. 7c).

\section{DISCUSSION}

\section{Epilepsy-prone phenotype of $\mathrm{mGluR7^{-/- }}$ mice, but not other mGluR-deficient mice}

In contrast to gene ablations of mGluR 1, 2, 4, 5, 6, and 8, respectively (Aiba et al., 1994; Conquet et al., 1994; Masu et al., 1995; Pekhletski et al., 1996; Yokoi et al., 1996; Lu et al., 1997; Duvoisin and Zhang, unpublished observations), gene disruption of mGluR7 predisposes to epilepsy. This points toward an important role of this particular group III mGluR in regulating the balance between excitatory and inhibitory transmission. The reduced thresholds for PTZ, bicuculline, and sensory stimulusevoked seizures in mGluR $7^{-1-}$ mice are acute results of the absence in adult tissue of a single or both isoforms of mGluR7 receptors. Alternatively, they are a consequence of absence of the receptor throughout development. Addressing these questions awaits the development of mGluR7-specific antagonists, conditional knock-outs, or mGluR $7^{-1-}$ mice in which receptor expression is reconstituted in the adult.

In either case the $\mathrm{mGluR} 7^{-/-}$mouse provides an interesting model of epilepsy, given that (1) the seizure susceptibility phenotype develops gradually, (2) they are uniquely associated with an ablation of this and no other mGluR subtype, and (3) when evoked by PTZ, the seizures are responsive to representatives of three major classes of anticonvulsants [ethosuximide is thought to act via modulation of $\mathrm{Na}^{+}$and $\mathrm{Ca}^{2+}$ channels (Coulter et al., 1989); clonazepam, a benzodiazepine, increases the frequency of $\mathrm{GABA}_{\mathrm{A}}$ receptor chloride channel opening and is especially potent in preventing PTZ-induced seizures (Henriksen, 1998); valproate is a drug with a broad preclinical and clinical profile but is poorly understood mechanistically (McLean and Macdonald, 1986; Kelly et al., 1990; Rogawski and Porter, 1990; Van Erp et al., 1990; Zona and Avoli, 1990)]. Apparently, mGluR7 does not contribute significantly to mechanisms underlying the actions of these antiepileptics.

In contrast, mGluR7 appears to be an important mediator of a mechanistically different (and potentially clinically viable) anticonvulsant principle, namely, the activation of group III mGluRs. This was shown here by using the group III mGluR selective agonist PPG, which proved effective against PTZ-induced seizures in mGluR4 $4^{-/-}, \mathrm{mGluR} 8^{-/-}$, and $\mathrm{mGluR} 7^{+/-}$, but not mGluR $7^{-/-}$, mice under experimental conditions in which PTZ evoked primarily clonic seizures. These findings are somewhat surprising, because PPG is least potent on mGluR7 of all of the human and rat recombinant group III mGluRs for the inhibition of forskolin-stimulated cAMP accumulation in mammalian cells (Nakajima et al., 1993; Okamoto et al., 1994; Conn and Pin, 1997; Gasparini et al., 1999). PPG also is anticonvulsant against soundinduced seizures in DBA/2 mice and genetically epilepsy-prone rats (Chapman et al., 1999) in the mouse maximal electroshock model (Gasparini et al., 1999) and in the mouse PTZ model (Fig. 5). Unlike L-AP4 and L-SOP, PPG lacks proconvulsant activity, and its anticonvulsant effects last much longer than those of L-AP4 or L-SOP (Chapman et al., 1999; Gasparini et al., 1999). However, PPG is not active when given systemically, and the compound has sedative effects (Chapman et al., 1999; our unpublished results). Therefore, novel compounds are needed to evaluate the potential of group III and, in particular, mGluR7selective drugs for treating epilepsy and/or other disorders (Masugi et al., 1999). A recent finding that further strengthens a role for mGluR7 receptors in epilepsy is its selective upregulation in the inferior colliculus of genetically epilepsy-prone (GEP) rats. This was shown to be associated with a prolonged anticonvulsant effect of intracollicular administrated L-SOP against soundinduced seizures in GEP rats (Yip et al., 2001).

One very limited gene polymorphism study in patients (Goodwin et al., 2000) could not provide a link between the mGluR7 gene and epilepsy. This also applies to other group III mGluRs. However, the mGluR7 gene spans $600 \mathrm{~kb}$ (http://www.ncbi.nlm. nih.gov/AceView/acegquery.cgi? $\mathrm{db}=300 \& \mathrm{ORG}=\mathrm{hs} \&$ term $=\mathrm{GM}$ M7), and more detailed studies need to be performed by using a large number of single nucleotide polymorphisms across the locus before any firm conclusions can be drawn regarding linkage to disease in human.

Interestingly, mGluR4 $4^{-/-}$compared with mGluR4 ${ }^{+/-}$mutant mice showed a differential resistance to absence-like seizures induced by $30 \mathrm{mg} / \mathrm{kg}$ PTZ (Snead et al., 2000). This finding seems to support a facilitating role of mGluR4 in absence-like seizures. At higher doses PTZ (40-60 mg/kg) evoked clonic convulsions and showed no difference in susceptibility between wild-type and mGluR4 ${ }^{-1-}$ mutant mice (Snead et al., 2000). PTZ injections (60 $\mathrm{mg} / \mathrm{kg}$ ) in mGluR4 ${ }^{-/-}$mice under our and different experimental conditions confirmed this. We failed to reveal a role for mGluR4 in mediating the anticonvulsant action of PPG in our PTZ paradigm, but another potent mGluR4 agonist has been 
shown to increase the latency of seizure onset in a different PTZ-induced tonic seizure paradigm (Thomsen and Dalby, 1998). Therefore, dependent on the seizure paradigm that is used, the role of particular group III mGluRs may differ.

This hypothesis is tempting, given findings in neuroprotection experiments. When we used different magnitudes of a toxic (NMDA) insult, low doses of PPG substantially reduced toxicity in $\mathrm{mGluR} 4^{+/-}$mice, but not in $\mathrm{mGluR} 4^{-/-}$mice, whereas higher doses were protective in both genotypes, suggesting that another receptor might play a more important role in protection at higher doses (Bruno et al., 2000).

\section{Potential mechanisms underlying the epileptic phenotype}

The very small excitability changes detected in the untreated mGluR $7^{-1-}$ hippocampal slices are consistent and correlate well with the absence of seizures in the $\mathrm{mGluR} 7^{-1-}$ mice in vivo under normal circumstances. The weak epileptogenic effects seen in $\mathrm{mGluR} 7^{-/-}$hippocampal slices with a subthreshold concentration of PTZ (for control slices) are consistent with the increased seizure susceptibility for PTZ in the $\mathrm{mGluR} 7^{-1-}$ mice in vivo. The lack of a difference between $\mathrm{mGluR} 7^{-1-}$ and their wild-type littermates in the excitability in slices exposed to PTZ and, in particular, at higher concentrations of PTZ is suggestive of a common expression mechanism, namely, a net reduction in GABAergic synaptic inhibition, for the two epileptogenic situations (absence of mGluR7 and presence of PTZ).

Recovery from facilitation reflects the restoration of presynaptic $\mathrm{Ca}^{2+}$ levels by extrusion while synapses are not active (Zucker, 1994; Fisher et al., 1997). Our results in the paired stimulus paradigms (Fig. 7) are consistent with the hypothesis that deletion of mGluR7 affects a (slow) component involved in presynaptic $\mathrm{Ca}^{2+}$ homeostasis. Resolving the underlying molecular mechanism remains a challenge, not only because of the multiple mechanisms implicated in presynaptic $\mathrm{Ca}^{2+}$ regulation $\left(\mathrm{Na}^{+}-\mathrm{Ca}^{2+}\right.$ exchange, uptake in mitochondria, the plasma membrane $\mathrm{Ca}^{2+}$ ATPase) [see Zenisek and Matthews (2000) and references therein] but also because mGluR7 has been linked to multiple effector pathways (Saugstad et al., 1996; Nakajima et al., 1999; O'Connor et al., 1999; Perroy et al., 2000). Regardless of which exact molecular mechanism will prove operational, a delayed recovery from facilitation as observed in $\mathrm{mGluR} 7^{-1-}$ slices may account, at least in part, for an epilepsy-prone phenotype, given that such alterations share some features that are observed when (presynaptic) $\mathrm{K}^{+}$channels are blocked by convulsant drugs (see, for example, Juhng et al., 1999). The mGluR7-deficient mouse adds to a large and growing list of novel models of epilepsy as a result of gene ablation, recently also including mice that lack the metabotropic receptor for GABA (Prosser et al., 2001; Schuler et al., 2001). Its uniqueness lies in the fact (1) that only few cases have been reported in which the epileptic phenotype is associated and/or caused by a specific presynaptic defect (such as synapsin deficiency; Rosahl et al., 1995) and (2) that no other mGluR gene ablation (mGluR1, 2, 4, 5, and 8) has resulted in an epileptic phenotype despite the fact that two of these receptors (mGluR4 and 8) have a strikingly similar presynaptic location. Given that mGluR4, mGluR7, and mGluR8 modulate different presynaptic parameters and show differential expression patterns (Shigemoto et al., 1997), these receptors might serve as distinct frequency-dependent synaptic transmission filters that accommodate fine tuning and information transfer under normal homeostatic and pathological conditions (for review, see Thomson,
2000). Dissecting the molecular signaling mechanisms underlying mGluR7 and its frequency-dependent regulation of neurotransmission may shed light on why this receptor might have potential as a drug target in epilepsy and/or other indications (Masugi et al., 1999).

\section{REFERENCES}

Aiba A, Kano M, Chen C, Stanton ME, Fox GD, Herrup K, Zwingman TA, Tonegawa S (1994) Deficient cerebellar long-term depression and impaired motor learning in mGluR1 mutant mice. Cell 79:377-388.

Allen KM, Walsh C (1996) Shaking down new epilepsy genes. Nat Med 2:516-518.

Anson J, Collins GG (1987) Possible presynaptic actions of 2-amino-4phosphonobutyrate in rat olfactory cortex. Br J Pharmacol 91:753-761.

Aronica EM, Gorter JA, Paupard MC, Grooms SY, Bennett MV, Zukin RS (1997) Status epilepticus-induced alterations in metabotropic glutamate receptor expression in young and adult rats. J Neurosci 17:8588-8595.

Barbarosie M, Avoli M (1997) CA3-driven hippocampal-entorhinal loop controls rather than sustains in vitro limbic seizures. J Neurosci 17:9308-9314.

Baskys A, Malenka RC (1991) Agonists at metabotropic glutamate receptors presynaptically inhibit EPSCs in neonatal rat hippocampus. J Physiol (Lond) 444:687-701.

Bate L, Gardiner M (1999) Genetics of inherited epilepsies. Epileptic Disord 1:7-19.

Bradley S, Levey AI, Hersch SM, Conn JP (1996) Immunocytochemical localization of group III metabotropic glutamate receptors in the hippocampus with subtype-specific antibodies. J Neurosci 16:2044-2056.

Brandstaetter JH, Koulen P, Kuhn R, van der Putten H, Waessle H (1996) Compartmental localization of a metabotropic glutamate receptor (mGluR7): two different active sites at a retinal synapse. J Neurosci 16:4749-4756.

Bruno V, Battaglia G, Ksiazek I, van der Putten H, Catania MV, Giuffrida R, Lukic S, Leonhardt T, Inderbitzin W, Gasparini F, Kuhn R, Hampson D, Nicoletti F, Flor P (2000) Selective activation of mGluR4 metabotropic glutamate receptors is protective against excitotoxic neuronal death. J Neurosci 20:6413-6420.

Bushell TJ, Jane DE, Tse HW, Watkins JC, Davies CH, Garthwaite J, Collingridge GL (1995) Antagonism of the synaptic depressant actions of L-AP4 in the lateral perforant path by MAP4. Neuropharmacology 34:239-241.

Cartmell J, Schoepp DD (2000) Regulation of neurotransmitter release by metabotropic glutamate receptors. J Neurochem 75:889-907.

Chapman AG, Nanan K, Yip P, Meldrum BS (1999) Anticonvulsant activity of a metabotropic glutamate receptor 8 preferential agonist $(R, S)$-4-phosphonophenylglycine. Eur J Pharmacol 383:23-27.

Conn PJ, Pin JF (1997) Pharmacology and functions of metabotropic glutamate receptors. Annu Rev Pharmacol Toxicol 37:205-237.

Conquet F, Bashir ZI, Davies CH, Daniel H, Ferraguti F, Bordi F, Franz-Bacon K, Reggiani A, Matarese V, Conde F, Collingridge GL, Crepel F (1994) Motor deficit and impairment of synaptic plasticity in mice lacking mGluR1. Nature 372:237-243.

Coulter DA, Huguenard JR, Prince DA (1989) Specific petit mal anticonvulsants reduce calcium currents in thalamic neurons. Neurosci Lett 13:74-78.

Davies J, Watkins JC (1982) Actions of D and L forms of 2-amino-5phosphonovalerate and 2-amino-4-phosphonobutyrate in the cat spinal cord. Brain Res 235:378-386.

Dietrich D, Kral T, Clusmann H, Friedl M, Schramm J (1999) Reduced function of L-AP4 metabotropic glutamate receptors in human epileptic sclerotic hippocampus. Eur J Neurosci 11:1109-1113.

Duvoisin RM, Zhang C, Ramonell K (1995) A novel metabotropic glutamate receptor expressed in the retina and olfactory bulb. J Neurosci 15:3075-3083.

Ferraro TN, Golden GT, Smith GG, St. Jean P, Schork NJ, Mulholland N, Ballas C, Schill J, Buono RJ, Berrettini WH (1999) Mapping loci for pentylenetetrazol-induced seizure susceptibility in mice. J Neurosci 19:6733-6739.

Fisher SA, Fisher TM, Carew TJ (1997) Multiple overlapping processes underlying short-term synaptic enhancement. Trends Neurosci 20:170-177.

Flor PJ, van der Putten H, Ruegg D, Lukic S, Leonhardt T, Bence M, Sansig G, Knopfel T, Kuhn R (1997) A novel splice variant of a metabotropic glutamate receptor, human mGluR7b. Neuropharmacology 36:153-159.

Frankel WN (1999) Detecting genes in new and old mouse models for epilepsy: a prospectus through the magnifying glass. Epilepsy Res 36:97-110.

Gasparini F, Bruno V, Battaglia G, Lukic S, Leonhardt T, Inderbitzin W, Laurie D, Sommer B, Varney MA, Hess SD, Johnson EC, Kuhn R, Urwyler S, Sauer D, Portet C, Schmutz M, Nicoletti F, Flor PJ (1999) 
$(R, S)$-4-phosphonophenylglycine, a potent and selective group III metabotropic glutamate receptor agonist, is anticonvulsive and neuroprotective in vivo. J Pharmacol Exp Ther 289:1678-1687.

Gereau 4th RW, Conn PJ (1995) Multiple presynaptic metabotropic glutamate receptors modulate excitatory and inhibitory synaptic transmission in hippocampal area CA1. J Neurosci 15:6879-6889.

Goodwin H, Curran N, Chioza B, Blower J, Nashef L, Asherson P, Makoff AJ (2000) No association found between polymorphisms in genes encoding mGluR7 and mGluR8 and idiopathic generalized epilepsy in a case control study. Epilepsy Res 39:27-31.

Henrikson O (1998) An overview of benzodiazepines in seizure management. Epilepsia 39[Suppl 1]:S2-S6.

Holmes KH, Keele NB, Shinnick-Gallagher P (1996) Loss of mGluRmediated hyperpolarizations and increase in mGluR depolarizations in basolateral amygdala neurons in kindling-induced epilepsy. J Neurophysiol 76:2808-2812.

Juhng KN, Kokate TG, Yamaguchi S, Kim BY, Rogowski RS, Blaustein MP, Rogawski MA (1999) Induction of seizures by the potent $\mathrm{K}^{+}$ channel-blocking scorpion venom peptide toxins tityustoxin-K $\alpha$ and pandinustoxin-K $\alpha$. Epilepsy Res 34:177-186.

Kelly KM, Gross RA, Macdonald RL (1990) Valproic acid selectively reduces the low-threshold $(\mathrm{T})$ calcium current in rat nodose neurons. Neurosci Lett 116:233-238.

Kinoshita A, Shigemoto R, Ohishi H, van der Putten H, Mizuno N (1998) Immunohistochemical localization of metabotropic glutamate receptors, mGluR7a and mGluR7b, in the central nervous system of the adult rat and mouse: a light and electron microscopy study. J Comp Neurol 393:332-352.

Kinzie JM, Saugstad JA, Westbrook GJ, Segerson TP (1995) Distribution of metabotropic glutamate receptor 7 messenger RNA in the developing and adult rat brain. Neuroscience 69:167-176.

Klapstein GJ, Meldrum BS, Mody I (1999) Decreased sensitivity to group III mGluR agonists in the lateral perforant path following kindling. Neuropharmacology 38:927-933.

Koerner JF, Cotman CW (1981) Micromolar L-2-amino-4phosphonobutyric acid selectively inhibits perforant path synapses from lateral entorhinal cortex. Brain Res 216:192-198.

Kosobud AE, Cross SJ, Crabbe JC (1992) Neural sensitivity to pentylenetetrazol convulsions in inbred and selectively bred mice. Brain Res 592:122-128.

Lanthorn TH, Ganong AH, Cotman CW (1984) 2-Amino-4phosphonobutyrate selectively blocks mossy fiber-CA3 responses in guinea pig but not rat hippocampus. Brain Res 290:174-178.

Liu AA, Becker A, Behle K, Beck H, Maltschek B, Conn PJ, Kuhn R, Nitsch R, Plaschke M, Schramm J, Elger CE, Wiestler OD, Blumcke I (2000) Up-regulation of the metabotropic glutamate receptor mGluR4 in hippocampal neurons with reduced seizure vulnerability. Ann Neurol 47:26-35.

Lu Y-M, Jia Z, Janus C, Henderson JT, Gerlai R, Wojtowicz JM, Roder JC (1997) Mice lacking metabotropic glutamate receptor 5 show impaired learning and reduced CA1 long-term potentiation (LTP) but normal CA3 LTP. J Neurosci 17:5196-5205.

Manzoni O, Bockaert J (1995) Metabotropic glutamate receptors inhibiting excitatory synapses in the CA1 area of rat hippocampus. Eur J Neurosci 7:2518-2523.

Markram H, L Jbke J, Frotscher M, Roth A, Sakmann B (1997) Physiology and anatomy of synaptic connections between thick-tufted pyramidal neurons in the developing rat neocortex. J Physiol (Lond) 500:409-440.

Masu M, Iwakabe H, Tagawa Y, Miyoshi T, Yamashita M, Fukuda Y, Sasaki H, Hiroi K, Nakamura Y, Shigemoto R (1995) Specific deficit of the ON response in visual transmission by targeted disruption of the mGluR6 gene. Cell 80:757-765.

Masugi M, Yokoi M, Shigemoto R, Muguruma K, Watanabe Y, Sansig G, van der Putten H, Nakanishi S (1999) Metabotropic glutamate receptor subtype 7 ablation causes deficit in fear response and taste aversion. J Neurosci 19:955-963.

McLean MJ, Macdonald RL (1986) Sodium valproate, but not ethosuximide, produces use- and voltage-dependent limitation of high frequency repetitive firing of action potentials of mouse central neurons in cell culture. J Pharmacol Exp Ther 237:1001-1011.

McNamara JO, Puranam RS (1998) Epilepsy genetics: an abundance of riches for biologists. Curr Biol 8:R168-R170.

Nakajima Y, Iwakabe H, Akazawa C, Nawa H, Shigemoto R, Mizuno N, Nakanishi S (1993) Molecular characterization of a novel retinal metabotropic glutamate receptor mGluR6 with a high agonist selectivity for L-2-amino-4-phosphonobutyrate. J Biol Chem 268:11868-11873.

Nakajima Y, Yamamoto T, Nakayama T, Nakanishi S (1999) A relationship between protein kinase $\mathrm{C}$ phosphorylation and calmodulin binding to the metabotropic glutamate receptor subtype 7 . J Biol Chem 274:27573-27577.

Neugebauer V, Keele NB, Shinnick-Gallagher P (1997) Loss of longlasting potentiation mediated by group III mGluRs in amygdala neurons in kindling-induced epileptogenesis. J Neurophysiol 78:3475-3478.

Neugebauer V, Zinebi F, Russell R, Gallagher JP, Shinnick-Gallagher P
(2000) Cocaine and kindling alter the sensitivity fo group II and III metabotropic glutamate receptors in the central amygdala. J Neurophysiol 84:759-770.

O'Connor V, El Far O, Bofill-Cardona E, Nanoff C, Freissmuth M, Karschin A, Airas JM, Betz H, Boehm S (1999) Calmodulin dependence of presynaptic metabotropic glutamate receptor signaling. Science 286:1180-1184.

Ohishi H, Akazawa C, Shigemoto R, Nakanishi S, Mizuno NJ (1995) Distributions of the mRNAs for L-2-amino-4-phosphonobutyratesensitive metabotropic glutamate receptors, mGluR4 and mGluR7, in the rat brain. J Comp Neurol 360:555-570.

Okamoto N, Hori S, Akazawa C, Hayashi Y, Shigemoto R, Mizuno N, Nakanishi S (1994) Molecular characterization of a new metabotropic glutamate receptor mGluR7 coupled to inhibitory cyclic AMP signal transduction. J Biol Chem 269:1231-1236.

Pekhletski R, Gerlai R, Overstreet LS, Huang XP, Agopyan N, Slater NT, Abramow-Newerly W, Roder JC, Hampson DR (1996) Impaired cerebellar synaptic plasticity and motor performance in mice lacking the mGluR4 subtype of metabotropic receptor. J Neurosci 16:6364-6373.

Perroy J, Prezeau L, De Waard M, Shigemoto R, Bockaert J, Fagni L (2000) Selective blockade of P/Q-type calcium channels by the metabotropic glutamate receptor type 7 involves a phospholipase $\mathrm{C}$ pathway in neurons. J Neurosci 20:7896-7904.

Pisani A, Calabresi P, Centonze D, Bernardi G (1997) Activation of group III metabotropic glutamate receptors depresses glutamatergic transmission at corticostriatal synapse. Neuropharmacology 36:845-851

Prosser HM, Gill GH, Hirst WD, Grau E, Robbins M, Calver A, Soffin EM, Farmer CE, Lanneau C, Gray J, Schenck E, Warmerdam BS, Clapham C, Reavill C, Rogers DC, Stean T, Upton N, Humphreys K, Randall A, Geppert M, Davies CH, Pangalos MN (2001) Epileptogenesis and enhanced prepulse inhibition in $\mathrm{GABA}_{\mathrm{B} 1}$-deficient mice. Mol Cell Neurosci 17:1059-1070.

Reyes A, Lujan R, Rosov A, Burnashev N, Somogyi P, Sakmann B (1998) Target cell-specific facilitation and depression in neocortical circuits. Nat Neurosci 1:279-285.

Rogawski MA, Porter RJ (1990) Antiepileptic drugs: pharmacological mechanisms and clinical efficacy with consideration of promising developmental stage compounds. Pharmacol Rev 42:223-286.

Rosahl TW, Spillane D, Missler M, Herz J, Selig DK, Wolff JR, Hammer RE, Malenka RC, Sudhof TC (1995) Essential functions of synapsin I and II in synaptic vesicles. Nature 375:488-493.

Rozov A, Burnashev N, Sakmann B, Neher E (2001) Transmitter release modulation by intracellular $\mathrm{Ca}^{2+}$ buffers in facilitating and depressing nerve terminals of pyramidal cells in layer $2 / 3$ of the rat neocortex indicates a target cell-specific difference in presynaptic calcium dynamics. J Physiol (Lond) 531:807-826.

Salt TE, Eaton SA (1995) Modulation of sensory neurone excitatory and inhibitory responses in the ventrobasal thalamus by activation of metabotropic excitatory amino acid receptors. Neuropharmacology 34:1043-1051.

Saugstad JA, Kinzie JM, Milvihill ER, Segerson TP, Westbrook GL (1994) Cloning and expression of a new member of the L-2-amino-4phosphonobutyric acid-sensitive class of metabotropic glutamate receptors. Mol Pharmacol 45:367-372.

Saugstad JA, Segerson TP, Westbrook GL (1996) Metabotropic glutamate receptors activate G-protein-coupled inwardly rectifying potassium channels in Xenopus oocytes. J Neurosci 16:5979-5985.

Schmutz M, Portet C, Jeker A, Klebs K, Vassout A, Allgeier H, Heckendorn R, Fagg GE, Olpe HR, van Riezen H (1990) The competitive NMDA receptor antagonists CGP37849 and CGP39551 are potent, orally active anti-convulsants in rodents. Naunyn Schmiedebergs Arch Pharmacol 342:61-66.

Schuler V, Lüscher C, Blanchet C, Klix N, Sansig G, Klebs K, Schmutz M, Heid J, Gentry C, Urban L, Fox A, Jaton A-L, Vigouret J-M, Pozza M, Kelly PH, Mosbacher J, Froestl W, Käslin E, Korn R, Bischoff S, Kaupmann K, van der Putten H, Bettler B (2001) Epilepsy, hyperalgesia, impaired memory, and loss of pre- and postsynaptic $\mathrm{GABA}_{\mathrm{B}}$ responses in mice lacking GABA B1 $_{\text {. Neuron } 31: 1-12 .}$

Semyanov A, Kullmann D (2000) Modulation of GABAergic signaling among interneurons by metabotropic glutamate receptors. Neuron 25:663-672

Shigemoto R, Kulik A, Roberts JDB, Ohishi H, Nusser Z, Kaneko T, Somogyi P (1996) Target cell-specific concentration of a metabotropic glutamate receptor in the presynaptic active zone. Nature 381:523-525.

Shigemoto R, Kinoshita A, Wada E, Nomura S, Ohishi H, Takada M, Flor PJ, Neki A, Abe T, Nakanishi S, Mizuno N (1997) Differential presynaptic localization of metabotropic glutamate receptor subtypes in the rat hippocampus. J Neurosci 17:7503-7522.

Snead III OC, Banerjee PK, Burnham M, Hampson D (2000) Modulation of absence seizures by the $\mathrm{GABA}_{\mathrm{A}}$ receptor: a critical role for metabotropic glutamate receptor 4 (mGluR4). J Neurosci 20:62186224 . 
Stuart GJ, Dodt HU, Sakmann B (1993) Patch clamp recordings from the soma and dendrites of neurons in brain slices using infrared video microscopy. Pfl $\int$ gers Arch 423:511-518.

Suzuki T, Shimizu N, Tsuda M, Soma M, Misawa M (1999) Role of metabotropic glutamate receptors in the hypersusceptibility to pentylenetetrazole-induced seizures during diazepam withdrawal. Eur J Pharmacol 369:163-168.

Tang E, Yip PK, Chapman AG, Jane DE, Meldrum BS (1997) Prolonged anticonvulsant action of glutamate metabotropic receptor agonists in inferior colliculus of genetically epilepsy-prone rats. Eur J Pharmacol 327:109-115.

Thomsen C, Dalby NO (1998) Roles of glutamate receptor subtypes in modulation of pentylenetetrazole-induced seizure activity in mice. Neuropharmacology 37:1465-1473.

Thomson AM (2000) Molecular frequency filters at central synapses. Prog Neurobiol 62:159-196.

Tizzano JP, Griffey KI, Schoepp DD (1995) Receptor subtypes linked to metabotropic glutamate receptor agonist-mediated limbic seizures in mice. Ann NY Acad Sci 765:230-235.

Van Erp MG, Van Dongen AM, Van den Berg RJ (1990) Voltagedependent action of valproate on potassium channels in frog node of Ranvier. Eur J Pharmacol 184:151-161.

Vignes M, Clarke VR, Davies CH, Chambers A, Jane DE, Watkins JC, Collingridge GL (1995) Pharmacological evidence for an involvement of group II and group III mGluRs in the presynaptic regulation of excitatory synaptic responses in the CA1 region of rat hippocampal slices. Neuropharmacology 34:973-982.

Wan H, Cahusac PM (1995) The effects of L-AP4 and L-serine- $O$ phosphate on inhibition in primary somatosensory cortex of the adult rat in vivo. Neuropharmacology 34:1053-1062.

White HS (1997) Clinical significance of animal seizure models and mechanism of action studies of potential antiepileptic drugs. Epilepsia 38[Suppl 1]:S9-S17.

Wong RK, Traub RD (1983) Synchronized burst discharge in disinhibited hippocampal slice. I. Initiation in CA2-CA3 region. J Neurophysiol 49:442-458.

Yip PK, Meldrum BS, Rattay M (2001) Elevated levels of group III metabotropic glutamate receptors in the inferior colliculus of genetically epilepsy-prone rats following intracollicular administration of L-serine-O-phosphate. J Neurochem 78:13-23.

Yokoi M, Kobayashi K, Manabe T, Takahashi T, Sakaguchi I, Katsuura G, Shigemoto R, Ohishi H, Nomura S, Nakamura K, Nakao K, Katsuki M, Nakanishi S (1996) Impairment of hippocampal mossy fiber LTD in mice lacking mGluR2. Science 273:645-647.

Zenisek D, Matthews G (2000) The role of mitochondria in presynaptic calcium handling at a ribbon synapse. Neuron 25:229-237.

Zona C, Avoli M (1990) Effects induced by the antiepileptic drug valproic acid upon the ionic currents recorded in rat neocortical neurons in cell culture. Exp Brain Res 81:313-317.

Zucker RS (1994) Calcium and short-term synaptic plasticity. Neth J Zool 44:495-512. 